$1-1-1981$

\title{
Competency to Stand Trial Under the Senate and House Proposed Revisions of the Federal Criminal Code
}

Leo M. Romero

University of New Mexico - School of Law

Follow this and additional works at: https://digitalrepository.unm.edu/law_facultyscholarship

Part of the Law Commons

\section{Recommended Citation \\ Leo M. Romero, Competency to Stand Trial Under the Senate and House Proposed Revisions of the Federal Criminal Code, 72 Journal of Criminal Law \& Criminology 434 (1981).}

Available at: https://digitalrepository.unm.edu/law_facultyscholarship/121

This Article is brought to you for free and open access by the UNM School of Law at UNM Digital Repository. It has been accepted for inclusion in Faculty Scholarship by an authorized administrator of UNM Digital Repository. For more information, please contact amywinter@unm.edu, Isloane@salud.unm.edu,sarahrk@unm.edu.

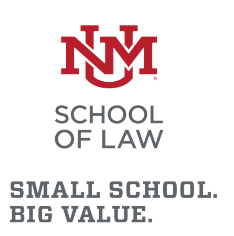

BIG VALUE. 


\title{
COMPETENCY TO STAND TRIAL UNDER THE SENATE AND HOUSE PROPOSED REVISIONS OF THE FEDERAL CRIMINAL CODE
}

\author{
LEO M. ROMERO*
}

In 1980 the judiciary committees of the Senate ${ }^{1}$ and the House of Representatives ${ }^{2}$ reported bills revising the federal criminal code. Although neither of these bills was enacted by the Ninety-Sixth Congress, they represent the culmination of efforts, over a period of a decade, to revise and reform the federal criminal laws in a comprehensive code.

The genesis of these efforts began with the Brown Commission Report in $1970 .^{3}$ Following the recommendations of the Brown Commission, a number of bills were introduced in each Congress since 1973 with the purpose of recodifying and reforming the federal criminal law and procedure. Each of the bills has included provisions to deal with offenders in the criminal system who suffer from some mental disability. ${ }^{4}$ The

* Professor of Law, University of New Mexico. The author wishes to acknowledge the valuable assistance of his research assistant, Mr. Kerry Kiernan, and wishes to express appreciation to his colleagues, Professor Luis G. Stelzner and Professor Joseph Goldberg, for their helpful comments.

1 S. 1722, 96th Cong., 1st Sess. (1980) [hereinafter cited as S. 1722]. The Senate bill was introduced on Sept. 7, 1979, and was entitled the Criminal Code Reform Act of 1979. The Senate Committee on the Judiciary reported the bill, with revisions, on Jan. 17, 1980. Commentary on this revised text of the bill is contained in S. REP. NO. 96-553, 96th Cong., 2d Sess. (1980).

2 H.R. 6915, 96th Cong., 2d Sess. (1980) [hereinafter cited as H.R. 6915]. The House bill was introduced on Mar. 25, 1980, and was entitled the Criminal Code Revision Act of 1980. The House Committee on the Judiciary reported the bill, with revisions, on Sept. 25, 1980. Commentary on this revised text is contained in H.R. REP. No. 96-1396, 96th Cong., 2d Sess. (1980).

3 The National Commission on Reform of Federal Criminal Laws, Study Draft of a New Federal Criminal Code (1970).

4 See H.R. 13959, 95th Cong., 2d Sess. $§ \S 21501-08$ (1978); S. 1437, 95th Cong., 1st Sess. $\S \S 3611-16$ (1977); H.R. 6869, 95th Cong., 1st Sess. $\$ \S 3611-17$ (1977); H.R. 2311, 95th Cong., 1st Sess. $\S \S 3611-14$ (1977); S. 1, 94th Cong., 1st Sess. $\$ \S 3611-17$ (1975); S. 1400, 93d Cong., 1st Sess. $\$ \S 4221-25$ (1973), reprinted in Hearing on $S . I$ and $S .1400$ Before the Subcomm. on Criminal Laws and Procedures of the Senate Comm. on the Judiciany, 93d Cong., 1st Sess. 5139-44 (1973) [hereinafter cited as 1973 Hearing]; S. 1, 93d Cong., 1st Sess. \$§ 3-11C1-3-11C8 (1973), reprinted in 1973 Hearing, supra, at 4400-07. None of these bills were enacted. 
latest of the bills, Senate Bill 1722 (S. 1722) ${ }^{5}$ and House Resolution 6915 (H.R. 6915), ${ }^{6}$ in the evolution of a new federal criminal code provide the most comprehensive procedures for such offenders.

This article will analyze and compare the provisions of both the Senate and House bills concerning the problem of the competency of a criminal defendant to stand trial. It will examine and evaluate the procedures for the determination of mental competency to stand trial and the procedures for the disposition of the incompetent defendant. Other related provisions in the bills, ${ }^{7}$ to the extent that they do not bear on the competency issue, are beyond the scope of this article. Finally, this article, in comparing the competency provisions in each bill, will show that the House bill is superior to the Senate version in many respects and thus should serve as the model for the next Congress in its efforts to revise the competency to stand trial provisions in the federal law.

\section{INTRODUCTION}

The adversary nature of the American criminal justice system requires that defendants in criminal cases be able to participate meaningfully in their defense. In order to participate meaningfully in their defense, defendants must be able to understand the nature of the charges against them and to assist their lawyer in preparing a defense. If a defendant lacks the ability to participate in his defense in this sense, he lacks the competency or fitness to stand trial. ${ }^{8}$ The conviction of a defendant who is incompetent to stand trial is a denial of due process guaranteed by the fifth and fourteenth amendments to the United

5 S. 1722 , supra note $1, \S \S 3611-17$.

6 H.R. 6915, supra note 2, $\$ \S 6121-29$.

7 Unrelated to this article is $\S 6128$ in H.R. 6915 concerning prisoner transfers to mental institutions. In S. 1722, the unrelated provisions include: $\$ 3612$, Determination of the Existence of Insanity at the Time of the Offense, $\S 3613$, Hospitalization of a Person Acquitted by Reason of Insanity; $\S 3614$, Hospitalization of a Convicted Person Suffering From Mental Disease or Defect; $\S 3615$, Hospitalization of an Imprisoned Person Suffering From Mental Disease or Defect; and §3616, Hospitalization of a Person Due for Release but Suffering From Mental Disease or Defect (to the extent that $\S 3616$ considers the disposition of prisoners whose sentences are about to expire).

8 See generally B. EnNis \& R. Emery, The Rights Of Mental Patients 98-108 (1978); H. Weihofen, Mental Disorder as a CRiminal Defense, 428-74 (1954); Eizenstat, Mental Competency to Stand Trial, 4 HARv. C.R.-C.L. REv. 379 (1969); Pizzi, Competengy to Stand Trial in Federal Courts: Conceptual and Constitutional Problems, 45 U. CHI. L. REV. 21 (1977); Silten \& Tullis, Mental Competency in Criminal Proceedings, 28 Hastings L.J. 1053 (1977); Note, Competence to Plead and the Retarded Defendant: United States v. Masthers, 539 F.2d 721 (D.C. Cir. 1976), 9 CoNN. L. REv. 176 (1976) [hereinafter cited as Competence to Plead]; Note, Incompetency to Stand Trial, 81 HaRv. L. REV. 454 (1967) [hereinafter cited as Incompelengy]; Mental Health Law Project, Incompetence to Stand Trial on Criminal Charges, 2 MeNTAL DisabiLrTY L. REP. 617 (1978). 
States Constitution. ${ }^{9}$ To convict an incompetent defendant offends due process in the sense that it is fundamentally unfair to convict a person who, in effect, is absent from the proceedings. ${ }^{10}$ In addition, there is concern about the accuracy of the factual determination of guilt where one side in the adversary system cannot participate. ${ }^{11}$ Relevant evidence on the issue of guilt or innocence is possessed by the defendant, and the availability of this evidence is often lost when the defendant is unable to understand the nature of the proceedings against him or unable to assist his counsel in his defense.

The present federal law dealing with the issue of competency is set forth in chapter 313 of title 18 of the United States Code. ${ }^{12}$ This chapter contains provisions concerning the procedure for the determination of competency prior to trial ${ }^{13}$ and the procedure for determining, after conviction, whether the defendant was competent to stand trial. ${ }^{14}$ In addition, the present federal statute authorizes indeterminate commitment of an incompetent defendant. ${ }^{15}$

The provisions in title 18 are not detailed. In addition, federal court decisions have added a substantial overlay of caselaw with respect to both the procedure for a competency determination and to the commitment of an incompetent defendant. ${ }^{16}$

9 Drope v. Missouri, 420 U.S. 162, 171-72 (1975); Pate v. Robinson, 383 U.S. 375,378 (1966).

10 See Drope v. Missouri, 420 U.S. at 170-72, where the Court considered this argument but found it unnecessary to base the due process violation on the in absentia ground. Instead, the Court said that competency is fundamental to a fair trial in an adversary system of justice. Id. at 171-72.

11 See A. Stone, Mental Health and Law: A System in Transition 203-04 (1975); Incompetency, supra note 8, at 457.

1218 U.S.C. $\S \S 4244-48$ (1976).

13 Id. $\S 4244$.

14 Id. $\$ 4245$.

15 Id. $\S \S 4246-48$.

16 See, e.g., Jackson v. Indiana, 406 U.S. 715 (1972); United States v. DiGilio, 538 F.2d 972 (3d Cir. 1976), cert. denied, 429 U.S. 1038 (1977); Eskridge v. United States, 443 F.2d 440 (10th Cir. 1971); In re Harmon, 425 F.2d 916 (1st Cir. 1970); Nelms v. United States, 318 F.2d 150 (4th Cir. 1963) (per curiam). In Jackson, the Court held that any defendant committed to an institution solely on account of his incapacity to stand trial could not be held more than a reasonable period of time necessary to determine whether there was a substantial probability that he would attain that capacity in the foreseeable future. 406 U.S. at 738. The current statutory provisions contain no such limitation. The DiGilio court held that the government had the burden in the competency hearing of proving competency by a preponderance of the evidence. 538 F.2d at 988 . Currently, 18 U.S.C. $\S 4244$ contains only the provision that the judge shall make a finding as to competency based on the evidence. In Eskridge, the court stated that the competency hearing should be adversarial in nature, and the defendant given the opportunity to cross-examine witnesses and present evidence of his own. $443 \mathrm{~F} .2 \mathrm{~d}$ at 442. 18 U.S.C. $\S 4244$ does not specifically provide this opportunity. The Hamon court further specified that any psychiatric report with respect to the defendant should be made available to the defendant prior to the competency hearing as a basis for the examination of the psychi- 
Both S. $1722^{17}$ and H.R. $6915^{18}$ include subchapters on competency concerning both the determination of competency and the incompetency commitment. Both bills are much more specific than title 18 of the United States Code and reflect major court decisions on the subject.

This article will first examine the provisions of each bill that pertain to the determination of competency. It will compare those provisions with the corresponding sections of title 18. The article will then analyze the provisions of each bill concerning the disposition of the incompetent defendant and compare them with the present federal law.

\section{Determination of Mental Competency to Stand Trial}

\section{A. RAISING THE COMPETENCY ISSUE}

\section{Who May Raise the Competency Issue?}

Both S. 1722 and H.R. 6915, like U.S.C. $\S 4244$, provide that the defendant, the attorney for the government, or the court may raise the question of the defendant's mental competency to stand trial. ${ }^{19}$ The defense counsel and the prosecutor must initiate the inquiry by a motion for a hearing to determine the mental competency of the defendant. The court may raise the issue on its own motion. ${ }^{20}$

atrist at the hearing. $425 \mathrm{~F} .2 \mathrm{~d}$ at 918 . Again, there is no such specific requirement in 18 U.S.C. \$ 4244. In regard to incompetency not disclosed at trial, the Nelms court held that a convicted person may challenge his conviction on the grounds of incompetency to stand trial without a certificate from the Director of Prisons stating that there was probable cause to believe that the person was mentally incompetent at the trial, as provided for in 18 U.S.C. $\S 4245$. Rather, the convicted person may, on his own initiative, file a motion for a hearing on the issue of incompetence undisclosed at trial under 28 U.S.C. $\$ 2255$ (1976), which is a collateral attack on the constitutionality of the conviction. 318 F.2d at 153.

17 S. 1722, supra note $1, \S \S 3611,3617$.

18 H.R. 6915, supra note $2, \S \S 6121-27$.

19 S. 1722, supra note $1, \S 3611$ (a); H.R. 6915 , supra note $2, \S \S 6121$ (a)-(b)(2). 18 U.S.C. $\S 4244$.

20 Some commentators have raised quesitons about permitting the prosecutor or the court to raise the competency issue for a variety of reasons. He may be charged with a misdemeanor, or he may have no prior record. In either of these events, the possibility of probation or short prison term may be more advantageous than a competency commitment. See Eizenstat, supra note 8, at 383-84; Incompetengy, supra note 8, at 466-68. In Carter v. United States, 283 F.2d 200 (D.C. Cir. 1960), moreover, the court stated that, from the appearance of the record before it, the appellant pleaded guilty to charges because basically the "appellant and his former counsel concluded that a jail sentence . . . would be preferable to a mental examination . . ., with the possibility thereafter of an extended period of confinement. . . ." Id. at 203.

On the other hand, the due process proscription against the conviction of an incompetent defendant may impose a constitutional requirement that the court raise the issue of competency if alerted to a competency question. See Drope v. Missouri, 420 U.S. at 181. The concern over an unconstitutional conviction may also give a prosecutor standing to raise the issue of a defendant's competency. See generally AMERICAN BAR Association PROJEct ON STANDARDS FOR CRIMINAL JUSTICE, Standards Relating to the Prosecution Function \$\$ 1.1(a)-(c) (1970). 
The standard for the court to apply in S. 1722 in deciding whether to order a competency hearing is one of reasonable cause to believe that the defendant may presently be suffering from a mental disease or defect rendering him unable to understand the nature and consequences of the proceedings against him or to assist in his defense. ${ }^{21}$ The reasonable cause standard is similarly employed in section 6121 of H.R. 6915 for ordering a screening examination ${ }^{22}$ and in the present federal law. ${ }^{23}$ The Senate bill does not require that the motion specifically state the specific facts in support of such an order although the Senate report assumes that this requirement exists by rule 47 of the Federal Rules of Criminal Procedure, which provides that all motions must state the grounds upon which they are made. ${ }^{24}$ Section 4244 of title 18 presently requires that the initiating motion set forth the grounds for the belief that the defendant may be incompetent. ${ }^{25}$ H.R. 6915, on the other hand, requires that the motion initiating the competency inquiry "allege specific facts." 26

The House provision concerning the content of the motion triggering the procedures for a determination of mental competency seems preferable. Even if the reasonable cause standard under the Senate version would require factual grounds, the specific requirement in H.R. 6915 that the motion shall allege specific facts eliminates any doubt that the contents of the motion must be factual. In addition, the decision to commence the procedural steps leading toward an incompetency determination should be based on articulable facts giving rise to a reasonable belief that the defendant may be mentally incompetent. ${ }^{27}$ This is an especially important decision-one which a defendant may oppose when the prosecutor or the court initiates the competency inquiry over

21 S. 1722, supra note $1, \S 3611$ (a).

22 H.R. 6915, supra note $2, \S 6121$ (a).

2318 U.S.C. $\$ 4244$.

24 The Senate Report states:

Under section 3611 (a) there is no specific requirement, as in 18 U.S.C. 4244 , that the motion set forth the grounds for the belief that the defendant is incompetent to stand trial: however, this requirement is incorporated into the statute by Rule 47 of the Federal Rules of Criminal Procedure which provides that all motions to the court must state the grounds upon which they are made. Of course, pursuant to that rule, the motion may be made orally, but grounds for the motion must still be stated.

S. REP. No. 96-553 at 1105 (footnotes omitted).

2518 U.S.C. $\$ 4244$.

26 H.R. 6915, supra note $2, \S 6121$ (b)(1).

27 Articulable facts are required under the fourth amendment in order to justify a finding of probable cause for an arrest or search or of reasonable suspicion to stop a person short of an arrest and to frisk. See Ybarra v. Illinois, 444 U.S. 85 (1979); Brown v. Texas, 443 U.S. 47 (1979); Delaware v. Prouse, 440 U.S. 648 (1979); United States v. Brignoni-Ponce, 422 U.S. 873 (1975); Terry v. Ohio, 392 U.S. 1 (1968). The purpose behind such a requirement is to insure that objective facts, rather than uncontrolled discretion, are the basis for a governmental intrusion into a person's privacy interests protected by the fourth amendment. 
the defendant's objection-and the decision should be based on objective facts so that the decision may be effectively reviewed. ${ }^{28}$ Indeed, H.R. 6915 requires that the court order initiating the competency determination include findings of fact supporting that order. ${ }^{29}$

A related issue concerns whether the court is obliged to initiate, on its own motion, the procedure for a competency determination when the court has some reason to believe the defendant is mentally ill. The Senate bill appears to require the court to order a competency hearing on its own motion if reasonable cause exists. ${ }^{30}$ The House version provides that the court may consider whether to commence the competency proceedings, ${ }^{31}$ thus indicating discretion on the part of the court, but another provision of H.R. 6915 suggests that the court must order the first step in the competency determination if reasonable cause exists to believe that a defendant lacks competence. ${ }^{32}$ No provision in title 18 concerns the presence or absence of discretion by the court in deciding to initiate competency proceedings. The constitutional basis underlying the competency issue probably requires the court to commence the competency inquiry whenever reasonable cause exists even in the absence of a motion by the defense or the prosecution. ${ }^{33}$ The failure to inquire into a defendant's competency may result in a conviction of an incompetent defendant and therefore violate due process of law. ${ }^{34}$

If the court is required to initiate competency proceedings on its own motion when reasonable cause exists to doubt the defendant's competency, the threshold issue is when does reasonable cause exist. This issue involves a case-by-case determination, for it is impossible to catalog the facts that either singly or in combination establish reasonable cause. If while presiding over pretrial proceedings or over the trial itself, the court observes or hears about matters that indicate reasonable cause as to a defendant's competency, it is then obliged to initiate the inquiry into competency. When this obligation arises is presently the subject of much litigation that develops on a case-by-case basis the type and quantum of evidence necessary to trigger the court's order of a competency

28 In addition to preventing arbitrary determinations, the requirement of articulable facts affords effective review of the trial court's determination. Id.

29 H.R. 6915, supra note $2, \S 6121$ (a).

30 Sections 3611 (a) provides that the court shall grant a motion for a competency hearing or shall order such a hearing on its own motion, if there is reasonable cause to believe that the defendant may presently be suffering from a mental disease or defect rendering him mentally incompetent to the extent that he is unable to understand the nature and consequences of the proceedings against him or to assist in his defense.

S. 1722, supra note $1, \S 3611$ (a).

31 H.R. 6915, supra note $2, \S 6121$ (b) (2).

32 Id. $\S 6121$ (a).

33 See Drope v. Missouri, 420 U.S. at 172-73; Pate v. Robinson, 383 U.S. at 384-86.

34 Id. 
inquiry on the court's own motion..$^{35}$

\section{When May the Question of Competency Be Raised?}

The Senate bill provides that an initiating motion may be made "[a]t any time after the commencement of a prosecution for an offense and prior to the sentencing of the defendant." 36 There is no provision for questioning the competency of a defendant after conviction to determine whether the conviction constituted a denial of due process. In contrast, H.R. 6915 and title 18 of the present federal law each include one provision that sets forth the procedures for determining competency prior to trial or sentencing, ${ }^{37}$ and another that establishes the procedure for determining competency after conviction when it was not raised prior to trial or sentencing. ${ }^{38}$

Under H.R. 6915, the issue of a defendant's mental competency to stand trial may be raised at any time before sentencing or during a postsentence hearing concerning revocation of parole or probation. ${ }^{39}$ Defense counsel, the attorney for the government, or the court may raise the issue at any of these times. If, however, the question of a defendant's incompetency is never raised prior to sentencing or during any revocation proceeding, section 6127 of H.R. 6915 provides for a procedure, similar to that found in 18 U.S.C. $\S 4245$, for determining, after the fact, whether a defendant was mentally incompetent at the time of the trial. If the Director of the Bureau of Prisons certifies that a defendant has been examined by the Board of Examiners at a federal penal or correctional institution and that there is probable cause to believe that such defendant lacked competence at the time of trial, the district court in which such defendant was convicted shall proceed with a determination of competency at the time of trial. ${ }^{40}$

In addition, the district court may proceed with a postconviction determination of competency to stand trial if the court has reason to believe, apart from a certification from the Bureau of Prisons, that a defendant was incompetent at the time of trial. ${ }^{41}$ Essential to either procedure for a postconviction determination of competency at the time of trial is the proviso that the issue of competency was not raised and deter-

35 See, e.g., United States v. Hayes, 589 F.2d 811 (5th Cir.), cert. denied, 444 U.S. 847 (1979); Reed v. United States, 529 F.2d 1239 (5th Cir.), cert. denied, 429 U.S. 887 (1976); King v. State, 581 S.W.2d 842 (Mo. App. 1979); Brady v. State, 584 S.W.2d 245 (Tenn. Crim. App. 1979); Johnson v. State, 583 S.W.2d 399 (Tex. Crim. App. 1979).

36 S. 1722, supra note $1, \S 3611($ a).

37 H.R. 6915 , supra note $2, \S 6121$; 18 U.S.C. $\$ 4244$.

38 H.R. 6915 , supra note $2, \S 6127$; 18 U.S.C. $\$ 4245$.

39 H.R. 6915 , supra note $2, \S 6121$ (c).

$40 \mathrm{Id}$. $\S \S 6127$ (a)-(b).

41 Id. $\$ 6127(\mathrm{~b})$. 
mined before or during such trial. ${ }^{42}$ The procedures for determining competency are essentially the same as those for the competency determination prior to trial. ${ }^{43}$ Although section 6127 of H.R. 6915 speaks in terms of competency at the time of trial, presumably these provisions would include a determination of competency at the time of a plea if a guilty plea was the basis of conviction. ${ }^{44}$

The House bill, by including a provision authorizing the court to raise the issue of competency after conviction, goes beyond 18 U.S.C. $\S 4245$ which, by its terms, permits a postconviction competency inquiry only upon a certificate from the Bureau of Prisons. ${ }^{45}$ Although H.R. 6915 specifically limits this authorization to the court, ${ }^{46}$ neither the defense counsel nor the attorney for the government are precluded from presenting other reasons to the court. The House version in effect permits the defense counsel or the prosecutor to raise the competency issue after conviction by presenting to the court reasons to believe that a defendant lacked competence at the time of trial.

The absence of any provision in S. 1722 for dealing postsentence with incompetency undisclosed at trial does not necessarily foreclose such a postconviction determination according to the Report of the Senate Judiciary Committee. The committee viewed the provisicns in rule 33 of the Federal Rules of Criminal Procedure ${ }^{47}$ as allowing a motion for a new trial on the basis of newly discovered evidence, that is, evidence of a defendant's incompetence at the time of trial. ${ }^{48}$

Notwithstanding the committee's hope that reasons indicating incompetency at the time of trial will "most likely" be considered newly discovered evidence warranting an inquiry into competency in a motion

42 Id. $\$ \S 6127(\mathrm{a})-(\mathrm{b})$.

43 Id. $\$ \S 6122-23,6127(\mathrm{~b})$.

44 If a person is competent to stand trial and therefore able to participate in a meaningful way in his own defense, he should also be competent to waive the constitutional rights that are part of a fair trial: right to trial by jury, right to present evidence, right to confront witnesses against him, and the privilege against self-incrimination. See United States ex rel. McGough v. Hewitt, 528 F.2d 339, 342 n.2-(3d Cir. 1975); Malinauskas v. United States, 505 F.2d 649, 654 (5th Cir. 1974); United States v. Harlan, 480 F.2d 515, 517 (6th Cir.), cert. denied, 414 U.S. 1006 (1973); People v. Heral, 62 Ill. 2d 329, 335, 342 N.E.2d 34, 37 (1976). In Heral, the court held that "a finding of competency to stand trial necessarily involves a finding that, with the advice and assistance of counsel, defendant is capable of waiving some or all of his constitutional rights, whether by a plea of guilty or during the course of his trial." Id.

4518 U.S.C. $\$ 4245$ only allows postconviction challenges by means of a certification of incompetency from the Director of the Bureau of Prisons.

46 H.R. 6915, supra note 2, §6127(b)(2).

47 "A motion for a new trial based on the ground of newly discovered evidence may be made only before or within two years after final judgment . . ." FED. R. CRIM. P. 33.

48 S. REP. No. $96-553$ at 1106. 
for a new trial, ${ }^{49}$ problems remain in the relegation of this question to the general postconviction remedy provisions in the federal code. First, evidence of a defendant's probable incompetency at the time of trial may not be considered newly discovered evidence necessitating a new trial under rule 33 of the Federal Rules of Criminal Procedure. The Supreme Court of the United States has never ruled specifically on whether mental incompetency may constitute newly discovered evidence under rule 33. The opinions of the federal courts of appeals, in setting forth the requirements for newly discovered evidence sufficient to require a new trial, do not clarify whether mental incompetency will meet the test for newly discovered evidence. Generally, for newly discovered evidence to warrant a new trial, (1) it must not have been discoverable pretrial by due diligence, (2) it must be material to the issue of guilt or innocence and not merely cumulative or impeaching, and (3) it must be such that its introduction would probably have produced a different result. ${ }^{50}$ The one circuit to consider whether mental incompetency constitutes newly discovered evidence held that it was not if the mental incompetency could have been discovered pretrial by due diligence of the defense counsel. ${ }^{51}$

Whether mental incompetency may be considered newly discovered evidence thus depends on the application of the traditional test for newly discovered evidence. To the extent that the traditional test imposed requirements that do not pertain to mental incompetence-for example, the requirement of materiality to guilt or innocence and the due diligence requirement-it is not so "likely" that the issue of competency may be raised posttrial in a rule 33 motion.

Under federal caselaw interpreting section 2255 of title 28 of the United States Code, ${ }^{52}$ a defendant may challenge a conviction on the

49 Id.

50 United States v. Zane, 507 F.2d 346, 347 (2d Cir. 1974), cert. denied, 421 U.S. 910 (1975).

51 United States v. Vowteras, 500 F.2d 1210, 1212 (2d Cir.), cert. denied, 419 U.S. 1069 (1974). The District of Columbia Circuit, in considering a different type of newly discovered evidence, has ruled that the due diligence requirement for newly discovered evidence should not apply to newly discovered evidence that calls into question the constitutional validity of the conviction. Marshall v. United States, 436 F.2d 155, 159 n.11 (D.C. Cir. 1970). As a conviction of a mentally incompetent defendant violates due process, the D.C. Circuit would apparently allow a motion for a new trial on the basis of newly discovered evidence of incompetency without a showing of due diligence.

52 Section 2255 states:

A prisoner in custody under sentence of a court established by Act of Congress claiming the right to be released upon the ground that the sentence was imposed in violation of the Constitution or laws of the United States, or that the court was without jurisdiction to impose such sentence, or that the sentence was in excess of the maximum authorized by law, or is otherwise subject to collateral attack, may move the court which imposed the sentence to vacate, set aside or correct the sentence.

A motion for such relief may be made at any time.

28 U.S.C. § 2255 (1976). 
ground that he was incompetent at the time of trial or at the time of the entry of a guilty plea. ${ }^{53}$ Before section 2255 may be used to inquire into the competency issue, a showing is necessary that the trial court did not consider and determine the issue at an evidentiary hearing under 18 U.S.C. $\S 4244 ;{ }^{54}$ or, if it did, a showing that the trial court's finding was clearly against the overwhelming weight of the evidence adduced at the competency hearing is required. ${ }^{55}$ The motion under section 2255 must in addition allege more than a bald and conclusory statement of incompetency. The motion must include specific factual allegations before the court is obligated to grant a hearing under section $2255 . .^{56}$

The availability of section 2255 to review after conviction a defendant's competency to stand trial is not preempted by the specific provisions of 18 U.S.C. $\S 4245$. Several circuits have ruled that a certificate from the Director of the Bureau of Prisons is not a prerequisite for a postconviction determination of the competency issue. ${ }^{57}$

53 See, e.g., Bishop v. United States, 350 U.S. 961 (1956) (per curiam), vacaling and remanding for a hearing, 223 F.2d 582 (D.C. Cir. 1955); Bryant v. United States, 468 F.2d 812, 813 (8th Cir. 1972); Hanson v. United States, 406 F.2d 199, 201 (9th Cir. 1969); Floyd v. United States, 365 F.2d 368, 376 (5th Cir. 1966); Nunley v. Taylor, 330 F.2d 611, 611 -12 (10th Cir. 1964) (per curiam), overnuling Nunley v. United States, 293 F.2d 651, 651-52 (10th Cir. 1960); United States v. Cannon, 310 F.2d 841, 843 (2d Cir. 1962); United States v. McNicholas, 298 F.2d 914, 916 (4th Cir.), cert. denied, 369 U.S. 878 (1962).

54 Hanson v. United States, 406 F.2d at 202; Grill v. United States, 363 F.2d 32, 32 (5th Cir. 1966) (per curiam); Bradley v. United States, 347 F.2d 121, 123 (8th Cir. 1965), cert. denied, 382 U.S. 1016, 385 U.S. 878 (1966). Under 18 U.S.C. § 4244, an evidentiary hearing is triggered only by the submission of a psychiatric report which indicates a state of present mental incompetency in the accused.

55 See Hanson v. United States, 406 F.2d at 202.

56 E.g. , Sanders v. United States, 373 U.S. 1, 19 (1963); Nolan v. United States, 466 F.2d 522, 524 (10th Cir. 1972); Hartman v. United States, 310 F.2d 447, 448 (6th Cir. 1962) (per curiam); Hayes v. United States, 305 F.2d 540, 543 (8th Cir. 1962).

57 E.g., Nelms v. United States, 318 F.2d at 153; United States v. Cannon, 310 F.2d at 843-44; United States v. Thomas, 291 F.2d 478, 480 (6th Cir. 1961); Simmons v. United States, 253 F.2d 909, 913 (8th Cir. 1958); Gregori v. United States, 243 F.2d 48, 54-55 (5th Cir. 1957).

In addition, an unsuccessful motion under section 2255 does not foreclose consideration of a subsequent motion under section 2255. See Sanders v. United States, 373 U.S. at 15-17, where the court held that controlling weight may be given to denial of a prior application for relief under $\S 2255$ only if (1) the same ground presented in the subsequent application was previously determined adversely to the applicant, (2) the prior determination was on the merits, and (3) the ends of justice would not be served by reaching the merits of the subsequent application. Consideration of the merits of a new application for relief can be avoided only if the government pleads that there has been an abuse of the remedy, such as when a prisoner deliberately withholds one of two grounds for relief at the time of his first application in the hope of being granted two hearings rather than one. Id. at 17-18. In terms of successive applications with regard to mental incompetency, if, for example, the first application merely contained a bald legal conclusion of incompetency and was therefore denied, a later application alleging certain facts regarding incompetency could be allowed, since the first application was not denied on the merits, but rather on the basis that the pleading was deficient. Id. at 19. 
The federal caselaw concerning section 2255 and postconviction review of competency at the time of trial appears to provide an adequate remedy without the need for additional statutory authority. S. 1722, however, makes no reference to section 2255. Since the Senate Judiciary Committee contemplated the availability of section 2255 as a means for a postconviction determination of competency, ${ }^{58} \mathrm{~S} .1722$ should explicitly recognize the section 2255 procedure. To the extent that postconviction determination of competency is expressly authorized in H.R. 6915 , the House version is preferable. Remedies and procedures that are part of a statutory scheme ought to be included in the statute itself, either by express language or by reference; the availability of any procedure should not be hidden only to be discovered by diligent legal research. $^{59}$

S. 1722 expressly ${ }^{60}$ and H.R. 6915 impliedly provide that a determination of competency does not foreclose subsequent determinations. The Senate Bill, like 18 U.S.C. $\S 4244$, is not specific, but the same authority for multiple determinations of competency may be implied from the language that provides that a motion may be made at any time after the commencement of a prosecution ${ }^{61}$ and that the court shall order a hearing to determine competency if there is reasonable cause to believe a defendant presently lacks competence. ${ }^{62}$ Because the standard for competency is the present ability to understand the nature of the proceedings and to assist counsel in his defense, a determination that a defendant is presently competent one day does not necessarily mean that such defendant will be competent the following week. ${ }^{63}$ If a de-

58 S. REP. NO. $96-553$ at 1106.

59 The concern for easy access to all procedures that permit a determination of competency, either pretrial or postconviction, is especially important to prison inmates whose prisons may lack the necessary library books or whose research skills are limited. This concern is easily resolved during the recodification process by simply referring to related procedures in the new statutory formulation or by incorporating such procedures into the recodification. H.R. 6915 has chosen the latter method with respect to a postconviction determination of competency ( $\$ 6127)$, whereas S. 1722 has opted for neither alternative.

60 H.R. 6915, supra note 2, $\$ 6121$ (c).

61 S. 1722, supra note $1, \S 3611$ (a); 18 U.S.C. $\S 4244$.

62 Id.

63 Many mental disorders are not static. Conditions and symptoms change, and the effect of the mental disorder on a defendant's competency may likewise change. The Supreme Court, in talking about the relationship between mental disorder and incompetence to stand trial, noted that "[e]ven when a defendant is competent at the commencement of his trial, a trial court must always be alert to circumstances suggesting a change that would render the accused unable to meet the standards of competence to stand trial." Drope v. Missouri, 420 U.S. at 181. Mental retardation, however, may be a mental condition that does not change. A determination of competency or incompetency may be valid for a substantial period of time. See P. Friedman, The Rights of Mentally Retarded Persons 142-43 (1976). Mental retardation is defined as "significantly subaverage general intellectual functioning existing concurrently with deficits in adaptive behavior and manifest during the developmen- 
fendant's mental condition deteriorates during the period prior to trial or sentencing, due process mandates a subsequent determination of then existing competency. ${ }^{64}$ To the extent that H.R. 6915 grants specific authority for subsequent determinations of competency, it is preferable to the implicit authority in the Senate version.

\section{B. PROCEDURES FOR THE DETERMINATION OF MENTAL COMPETENCY TO STAND TRIAL}

A two-stage procedure determines mental competency to stand trial after the court finds reasonable cause to believe a defendant lacks such competence. The first stage involves the mental competence examination; the second consists of a hearing to determine competency.

\section{Procedure for the Mental Competence Examination}

If the court orders a competency hearing, the court may require, prior to the hearing, a psychiatric examination of a defendant and a psychiatric report to be filed with the court. ${ }^{65}$ This mental examination is discretionary with the court under S. 1722 although the Report of the Senate Judiciary Committee states that a psychiatric examination will be routine in virtually all cases in which a hearing is ordered. ${ }^{66}$ Apparently the committee foresaw situations where a determination of competency can be made without a psychiatric examination. Such situations might include instances where a defendant is comatose or disoriented as to time and place. Apart from these cases, a psychiatric examination would always be warranted because the competency question involves a determination of present competency. ${ }^{67}$

Unlike the Senate bill, H.R. 6915 provides for two types of mental examinations. The first examination is a screening examination when-

tal period." AMERICAN ASSOciation on MENTAL Deficiency, ManUal on TERMinOLOGY \& Classification in Mental Retardation 5 (Grossman ed. 1973). See also the definition in The American Psychiatric Association, Diagnostic and Statistical Manual of MENTAL Disorders 14 (2d ed. 1968). The phrase "manifest during the developmental period" implies the presence of a long-term, static disability. A real problem concerning retardation and competency to stand trial, in fact, is that often courts treat the retarded offender as if he was competent because of factors such as a general passive demeanor displayed in court. See Competence to Plead, supra note 8, at 176.

64 Drope v. Missouri, 420 U.S. at 181; Pate v. Robinson, 383 U.S. 375, 384-85 (1966).

65 S. 1722, supra note $1, \S 3611$ (b).

66 S. REP. NO. $96-553$ at 1106.

67 Thus, a prior history of mental illness, made known to the court, would be an insuffcient basis for a determination of present incompetency without a psychiatric examination. See United States v. Bass, 477 F.2d 723 (9th Cir. 1973), and United States v. McEachern, 465 F.2d 833 (5th Cir.), cett. denied, 409 U.S. 1043 (1972), in which the appellate courts recognized that a psychiatric examination was required when the defendant merely stated before trial that he had previous mental problems. Both Bass and McEachem, however, were decided under 18 U.S.C. $\$ 4244$, where a psychiatric exam was clearly required, and was not discre- 
ever the court finds reasonable cause to believe a defendant lacks competence. ${ }^{68}$ The purpose of the screening examination is to provide the court with a basis for deciding whether a defendant is competent or whether a more thorough mental competency examination is necessary to determine competence. ${ }^{69}$ The results of the screening examination must be reported to the court within three days. ${ }^{70}$ If the court finds a defendant competent after receiving the results of the screening examination, the case proceeds to trial unless the defendant objects and requests a more thorough mental examination. ${ }^{71}$ Such a request requires the court to hold a hearing within forty-eight hours to determine whether a more thorough examination of the defendant is necessary to ascertain his competence. ${ }^{72}$ The court must order such an examination if it finds, after the screening examination or after a hearing on the issue of a more thorough examination, that such an examination is necessary to determine competence. ${ }^{73}$

The bills also differ in defining who is competent to conduct a mental competence examination. The psychiatric examination authorized by S. 1722 must be conducted by either a licensed or certified psychiatrist or by a team consisting of a clinical psychologist and a medical doctor. ${ }^{74}$ Thus, neither a clinical psychologist nor a medical doctor who is not a psychiatrist may alone conduct the mental examination. Only a psychiatrist may conduct such an examination alone. Each examiner must be designated by the court. The court, however, in its discretion may designate additional examiners. ${ }^{75}$

The House bill differs from S. 1722 in its definition of the qualifica-

tionary, whenever there was reasonable cause to believe that a defendant might be presently incompetent.

Even a prior determination of incompetency may be insufficient to support a finding of present incompetency although, if the past determination was close enough in time, such evidence may permit a new determination without a new psychiatric examination. Whether such a prior determination of incompetency would be sufficient to dispense with a psychiatric examination would then be a matter within the discretion of the court. $C f$. United States v. Bodey, 547 F.2d 1383 (9th Cir.), cert. denied, 431 U.S. 932 (1977), and United States v. Cook, 418 F.2d 321 (9th Cir. 1969) (holding that the grant of a second psychiatric examination after an initial finding of competency depends on such factors as the length of time between the first exam and the request for another exam, and on the showing made for the second exam, and that generally such a decision rests in the discretion of the trial court).

68 H.R. 6915 , supra note $2, \S 6121$.

$69 \mathrm{Id}$. $\$ 6122(\mathrm{a})$. Another purpose of the screening examination, according to the House Report, is to avoid frivolous motions and unnecessary, prolonged examinations. H.R. REP. No. $96-1396$ at 552.

70 H.R. 6915, supra note $2, \S 6121$ (d).

71 Id. $\S 6122(\mathrm{~b})$.

$72 \mathrm{Yd}$.

73 Id. $\$ 6122(\mathrm{c})$.

74 S. 1722, supra note $1, \S 3617$ (b). See S. REP. No. $94-533$ at 1106.

75 S. 1722 , supra note $1, \S 3617(\mathrm{~b})$. 
tions of the persons authorized to conduct the screening examination and the more thorough mental competency examination under H.R. 6915. The House bill uses the term "a qualified health examiner,"76 which is defined as either (1) "a physician who has completed three years of residency training in psychiatry in a program approved by the American Medical Association," or (2) "a person who has received a doctoral degree in a clinical program accredited by the American Psychological Association and who has at least three years experience in the treatment and diagnosis of serious mental diseases or defects."77 The Senate version, by way of comparison, imposes no training qualifications beyond licensing or certification of a psychiatrist, medical doctor, or clinical psychologist. ${ }^{78}$ H.R. 6915 also differs from the Senate bill by authorizing each of its two types of examinations to be conducted by a single qualified health examiner. ${ }^{79}$ S. 1722 , on the other hand, permits only a psychiatrist to perform the examination alone. ${ }^{80}$

A further difference between the two bills concerns the disqualification of certain examiners under the House bill. H.R. 6915 provides that the thorough mental competency examination shall not be conducted by a qualified examiner who is on the staff of an institution to which the defendant may be sent if the defendant is found to lack competence. ${ }^{81}$ No such limitation exists for the psychiatric examination under the Senate bill. Because there may be an institutional interest in the competency determination if the institution which employs the examiner may receive the defendant as a patient, ${ }^{82}$ the House bill is preferable in its elimination of any possible interest or bias by the examiner.

\section{Commitment and Alternatives to Commitment for the Mental Competence Examination}

The Senate bill authorizes the court to commit a defendant for examination as to mental competence. The commitment is to the Attorney General for placement in a.suitable facility defined as a facility that is suitable to provide care or treatment given the nature of the offense and the characteristics of the defendant. ${ }^{83}$ Commitment is discretionary

76 H.R. 6915, supra note 2, §§ 6121(d), 6122(d)(1).

77 Id. $\$ 6129$ (a)(2).

78 S. 1722 , supra note $1, \S 3617$ (b).

79 H.R. 6915, supra note 2, $\S \S 6121$ (d), 6122(d)(1).

80 S. 1722 , supra note $1, \S 3617$ (b).

81 H.R. 6915, supra note 2, §6122(d)(1).

82 See Gray, The Insanity Defense: Historical Development and Contemporary Relevance, 10 AM. CRIM. L. REV. 559, 579-82 (1972); Mental Health Law Project, supra note 8, at 622.

83 S. 1722, supra note $1, \S \S 3617$ (a)(3), 3617(b). 
with the court, ${ }^{84}$ but S. 1722 provides no guidelines for the exercise of the court's discretion. The Report of the Senate Judiciary Committee notes that the court may order a mental examination without commitment if the court believes that the defendant's examination can be conducted on an outpatient basis. ${ }^{85}$ Again, the Senate Report lists no factors that the court should consider in deciding whether to commit or to utilize an outpatient facility.

The House bill, on the other hand, does not permit commitment for the initial screening examination. The screening examination may be conducted at either the place of confinement if the defendant is detained pretrial, or on an outpatient basis if the defendant is at liberty on bail. ${ }^{86}$

For the more thorough mental competency examination, H.R. 6915 authorizes commitment to a mental health facility but sets forth a presumption against such commitment. In order to warrant a commitment of a defendant, the court must conclude, supported by findings of fact, that one of four conditions exists: (1) residence or confinement is necessary for the examination; (2) residence or confinement is necessary because the defendant has failed to appear for such examination or similar examinations in the past; (3) the defendant presents a substantial probability of serious bodily injury to any person or substantial damage to the property of others; or (4) the defendant is not otherwise released from pretrial confinement. ${ }^{87}$ The House version thus does not automatically penalize a defendant-by an involuntary commitment for examination when such defendant is not detained pretrial. His liberty is respected, and the examination must take place on an outpatient basis unless one of the conditions for commitment exists. ${ }^{88}$

Although no hearing for a determination of commitment for examination is explicitly authorized by H.R. 6915, a hearing requirement may be implied from the necessity that such a commitment be supported by findings of fact. ${ }^{89}$ Presumably a defendant's objection to an examination commitment would trigger a hearing on this limited issue. If not, a defendant may attempt to gain his release from such a commitment by

84 Id. $\S 3617(\mathrm{~b})$. This section states that the court "may" commit, rather than "shall" commit.

85 S. REP. NO. 96-553 at 1107.

86. H.R. 6915 , supra note $2, \S 6121$ (d).

87 Id. $\S 6122(\mathrm{~d})(2)$.

88 See generally Marcey v. Harris, 400 F.2d 772, 774 (D.C. Cir. 1968), where the court ruled that, on the request of the defendant, his commitment for purposes of a pretrial mental examination shall be limited to examination on an outpatient basis unless the court is advised by a report from hospital authorities setting forth reasonable grounds that an inpatient commitment is necessary to assure an effective examination; Golten, Role of Defense Counsel in the Criminal Commitment Process, 10 AM. CRIM. L. REV. 385, 390-92 (1972); Mental Health Law Project, supra note 8 , at $622-23$.

89 H.R. 6915, supra note $2, \S 6122(\mathrm{~d})(2)$. 
means of a writ of habeas corpus, which is specifically recognized as an available remedy to challenge a commitment for treatment.90 The House bill, however, does not explicitly include a challenge to a commitment for a mental examination by writ of habeas corpus. This oversight, if not corrected in the legislative process, should be corrected by court interpretation that would permit any commitment authorized by H.R. 6915 to be challenged by a writ of habeas corpus. ${ }^{91}$

\section{Duration of the Mental Competence Examination}

The Senate bill sets no time limits for an outpatient examination. If, however, the court commits a defendant for a psychiatric examination, the commitment is limited to a reasonable period not to exceed thirty days. ${ }^{92}$ A court could choose a shorter period of time as reasonable. The director of the facility to which the defendant is committed may apply for a reasonable extension but not more than an additional fifteen days upon a showing of good cause that such an extension is necessary to observe and evaluate the defendant. ${ }^{93}$ Although an extension order by the court is not explicitly authorized in S. 1722, presumably a court has the power on its own motion to extend the commitment for a period it deems reasonable, up to fifteen days, upon a showing of good cause. ${ }^{94}$

If a person is committed beyond the period authorized by S. 1722, habeas corpus would be available to challenge such a commitment according to the Report of the Senate Judiciary Committee. ${ }^{95}$ No other remedy for a commitment extended beyond the maximum period was contemplated by the Senate Judiciary Commmittee. In fact, the Senate Report states that the report of the psychiatric examination is not rendered inadmissible at a competency hearing by reason of an unauthorized extension. ${ }^{96}$

90 "Nothing contained in this sub-chapter precludes a defendant who is committed for treatment under this sub-chapter from establishing by writ of habeas corpus the defendant's eligibility for release under this sub-chapter." Id. $\$ 6129(b)$.

91 Although the commitment for treatment is different in purpose and duration from a commitment for a mental examination, the House bill contemplates that each type of commitment must comply with the requirements set forth. Any commitment that does not meet these requirements is an unlawful commitment and should be subject to habeas corpus relief. The failure of $\S 6129$ (b) to explicitly include a challenge to a commitment examination may be a drafting oversight that does not indicate a legislative intent to preclude a habeas corpus challenge to such a commitment.

92 S. 1722, supra note $1, \S 3617$ (b).

93 Id.

94 Section $3617(\mathrm{~b})$ assumes that the court will order an extension, but the bill does not expressly authorize the court to issue such an order.

95 S. REP. No. 96-553 at 1107.

96 Id. 
H.R. 6915, unlike S. 1722, does not impose any limit on the duration of a mental competency commitment. Instead, H.R. 6915 establishes time limits on the filing with the court of the report by the qualified mental health examiner making the thorough mental examination. These time limits apply to examinations conducted on an outpatient basis or at a mental health facility to which the defendant is committed. ${ }^{97}$ The time limits prescribed by H.R. 6915 are somewhat shorter than those specified in S. 1722. The report must be filed with the court within fifteen days although the court may extend this period to the extent necessary to permit the transportation of a defendant to and from a designated nonlocal facility to which he is committed. ${ }^{98} \mathrm{In}$ addition, the court may extend the fifteen-day period on the motion of any party if the court finds that specific additional examinations or procedures are necessary to a determination of the defendant's competence and that an extension is required for such examinations or procedures. ${ }^{99}$ The extension of time for the filing of the report with the court may not exceed an additional thirty days. ${ }^{100}$ Although no hearing on the extension is explicitly provided in H.R. 6915, such a hearing is apparently contemplated in the language requiring a motion and court findings to justify the extension.

The Senate bill requires a psychiatric report based upon the examination of the defendant to be filed with the court. ${ }^{101}$ Unlike H.R. 6915, and like title $18,{ }^{102}$ there is no time limitation on the submission of the report to the court. The report need not be filed within the authorized period of commitment for an examination if commitment is ordered, and the report need not be filed within any time period if the examination is conducted on an outpatient basis. The absence of any time limits for submission of the psychiatric report may result in a substantial delay prior to the competency determination. The delay may be significant if the defendant is found to be competent as the delay may have speedy trial implications. ${ }^{103}$ If the defendant is found to be incompetent, the

\footnotetext{
97 H.R. 6915, supra note 2, §6122(e)(2).

98 Id. $\S 6122(\mathrm{e})(2)(\mathrm{A})$.

$99 \mathrm{Id} . \S 6122(\mathrm{e})(2)(\mathrm{B})$.

$100 \mathrm{Id}$.

101 S. 1722 , supra note $1, \S 3617$ (c).

10218 U.S.C. $\$ 4244$.

103 "In all criminal prosecutions, the accused shall enjoy the right to a speedy and public trial . . ." U.S. CoNST. amend. VI. In Barker v. Wingo, 407 U.S. 514 (1972), the Supreme Court announced a four-factor balancing test for determining when this constitutional right to a speedy trial has been denied a defendant. These factors are: (1) the length of the delay in the proceedings; (2) the reason for the delay (such as whether the defense or prosecution caused the delay and, if the latter, the degree of good faith effort expended in bringing the case to trial as soon as possible); (3) whether and when the defendant asserted his right to a speedy trial, and (4) whether any actual prejudice to the defendant resulted from the delay
} 
delay may mean that a defendant is not provided necessary treatment during the period of delay.

The House bill is preferable in its specification of time limits for submission of the report. Even without explicit limits in S. 1722, however, the court should have the inherent power to prevent delays in the filing of such reports with the court. The court's authority to order the

due to destruction or staleness of evidence, oppressive pretrial incarceration, or the creation of excessive anxiety. Id . at 530-33. A finding that the right has been denied then requires dismissal of the indictment against the defendant. Id. at 522. However, the Court refused to indicate a specified time period within which a trial must take place, preferring to leave such rulemaking activity to the legislative branch of government. Id. at 523 .

The Federal Speedy Trial Act, 18 U.S.C. $\$ \S 3161-74$ (1976 \& Supp. III 1979), provides for specific periods within which indictments must be filed and trials must be held. Failure to comply with the time limits prescribed by the Act results in the dismissal of the indictment although discretion is given to the trial judge to dismiss the case with or without prejudice. Id. $\S 3162(\mathrm{a})$. However, certain periods of delay are to be excluded in computing the time limits, such as delay resulting from any proceeding, including any examinations to determine the mental competency or physical capacity of the defendant. Id. $\$ 3161(\mathrm{~h})(1)(\mathrm{A})$. Whether the absence of time limits in S. 1722 for the submission of the psychiatric report after the examination might cause dismissal of the case is left unclear under the Speedy Trial Act, although the exclusion of delays for examinations gives a strong implication from $\S 3161(\mathrm{~h})(\mathrm{l})$ (A) that the absence of such limits in S. 1722 would not cause dismissal.

The Speedy Trial Act provides, however, that none of its provisions are to be interpreted as a bar to a claim of denial of speedy trial as required by the sixth amendment. Id. $\S 3173$. Thus, even if a defendant cannot make out a violation of his statutory right, he may still argue his constitutional claim. Courts have held that confinement in mental institutions for purposes of determining competency to stand trial and for purposes of restoring competency does not violate the defendant's right to a speedy trial under the sixth amendment. E.g., United States v. Davis, 365 F.2d 251, 255-56 (6th Cir. 1966); Johnson v. United States, 333 F.2d 371, 374 (10th Cir. 1964); Nickens v. United States, 323 F.2d 808, 811 (D.C. Cir. 1963), cert. denied, 379 U.S. 905 (1964). Yet, federal courts have not specifically dealt with the issue of whether psychiatric reports composed after the confinement examination must be timely submitted to the court. The length of time in any particular case between the completion of the examination and the submission of the report to the court must then be analyzed using the Barker four-factor balancing test to determine if the right to a speedy trial has been denied a defendant. In Barker, the Supreme Court regarded none of the four factors as determinative; rather, they were balanced against one another in deciding whether the speedy trial right has been denied. 407 U.S. at 533. Suppose, for example, that a defendant decides to appeal his conviction on the basis of a deprivation of the speedy trial right, and he submits the following facts for review: (1) the psychiatrist, due to his own carelessness, did not submit his finding of competency until several months after the examination of the defendant; (2) the defendant continually during the delay asserted his right to a speedy trial; and (3) during this delay a key defense witness died thereby greatly prejudicing the defendant. A strong argument could be made that under the balancing test the right to speedy trial had been denied, and that such a denial would result in reversal of the conviction and in dismissal of the indictment. The delay in this situation, of course, is not properly the fault of either the defense or the prosecution where the psychiatrist is really appointed by the court (as in S. 1722). However, the Barker case noted that the primary burden for bringing cases to trial is on the prosecutor and the court. Id. at 529. Therefore, the court could be considered negligent in not monitoring diligently the activities of the psychiatrist, and this negligence would certainly be an important factor for tipping the balance in favor of the defendant's claim of deprivation of speedy trial rights. 
filing of a report ${ }^{104}$ may implicitly empower the court to set a deadline for submission of the report.

\section{Requirement for the Report on the Mental Competence Examination}

The psychiatric report filed with the court under S. 1722 must also be provided to the counsel for the defendant examined and to the attorney for the government. ${ }^{105}$ By sending a copy of the report to defense counsel, counsel may determine whether in his judgment it is appropriate, useful, or harmful for his client to see the report. ${ }^{106}$ The House version likewise requires that copies of the report of the mental competency examination be provided to the counsel for the defendant and to the attorney for the government. ${ }^{107}$

The contents of the report of the psychiatric examination submitted pursuant to court order under S. 1722 must include the bases of the opinions in addition to the opinions of the examiner. In particular, the report must include (1) the defendant's history and present symptoms, (2) a description of the psychological and medical tests employed and their results, (3) the examiner's findings, and (4) the examiner's opinions as to diagnosis, prognosis, and whether the person is presently suffering from a mental disease or defect rendering him mentally incompetent to the extent that he is unable to understand the nature and consequences of the proceedings against him or to assist properly in his defense. ${ }^{108} \mathrm{~S}$. 1722 thus requires the report to state the examiner's conclusion with respect to the legal standard for incompetency.

The House bill similarly specifies the required contents of the mental competency examination report. ${ }^{109}$ There are no content requirements, however, for the preliminary screening examination under H.R. 6915. ${ }^{110}$ The more thorough mental examination report of H.R. 6915 must include essentially the same information and opinions required in S. 1722. The House bill, though, sets forth some additional content requirements. For example, H.R. 6915 mandates that the re-

104 S. 1722, supra note $1, \S 3611$ (b).

105 Id. § 3617(c). According to the Senate Judiciary Committee, the report must be sent to counsel for the defendant, rather than to the defendant himself, so that counsel may determine whether it would be appropriate or useful for the defendant to see the report. S. REP. No. $96-553$ at 1107 n.17.

106 Id.

107 H.R. 6915, supra note $2, \S 6122(\mathrm{e})(2)$.

108 S. 1722 , supra note $1, \S \S 3617(1)-(3), 3617(4)$ (A); S. REP. No. $96-553$ at 1107.

109 H.R. 6915, supra note $2, \S \S 6122(\mathrm{~A})$-(F). This is the more thorough mental examination which follows the initial screening examination of $\S 6121$.

$110 \mathrm{Id} . \S 6121$ (d). This section stipulates merely that a screening exam shall be performed by a qualified mental health examiner, and that the examiner shall report the results to the court. The court shall then determine what the results indicate. Id. $\$ 6122(a)$. See text accompanying notes $68-71$ supra. 
port include (1) psychological and neurological test data, (2) the assumptions of the diagnosticians in performing evaluations, and (3) all medical records made in the course of the examination, together with any minutes or videotape of any staff conference held in the course of the examination. ${ }^{111}$ These additional requirements provide the court with more information relevant to the validity of the opinions contained in the report.

The House bill also calls for an opinion by the examiner on a critical issue involved in the incompetency determination and commitment. The report must include a prognosis for the immediate future, both with and without treatment. ${ }^{112}$ This opinion is valuable to the court because the likelihood of regaining competency is important to the disposition of an incompetent offender. ${ }^{113}$ Although this opinion may be called for under S. 1722, ${ }^{114}$ the language in H.R. 6915 is much more specific in terms of the medical findings required. Whereas $\mathrm{S}$. 1722 provides that the report shall include the examiner's findings and opinions, ${ }^{115}$ H.R. 6915 states that the report must contain the examiner's conclusions concerning the mental and emotional functioning of the defendant, specifying the basis for such conclusions and including the nature and severity of any impairments as of the present time. ${ }^{116}$

The House bill, unlike the Senate bill, does not require an opinion in the report on whether the defendant is incompetent. Instead, H.R. 6915 provides that the report shall include such an opinion only if the examiner feels such opinion to be within the examiner's expertise. ${ }^{117}$ To the extent that a qualified mental health examiner considers the issue of competency to be a legal rather than a medical issue, H.R. 6915 does not require an opinion on the issue of competency. By not requiring an opinion on the ultimate issue, by requiring more of the information on which the medical opinions are based, and by requiring more specific medical conclusions that are directly pertinent to the competency issue, H.R. 6915 attempts to leave the determination of competency, a legal issue, to the court, and to provide the court with sufficient information upon which to make its determination. ${ }^{18}$ The Senate bill, on the other

111 Id. $\S \S 6122(\mathrm{e})(3)(\mathrm{B}), 6122(\mathrm{e})(3)(\mathrm{E})$.

$112 \mathrm{Id} . \S 6122(\mathrm{e})(3)(\mathrm{D})$.

$113 \mathrm{Id}$. $\$ \S 6123(\mathrm{~b})(2), 6123$ (c)(2). See text accompanying notes 231-48 infra.

114 Under S. 1722, supra note $1, \S 3617$ (c)(4), the examiner is required to give his opinion as to prognosis, but there is no specification that there be two prognoses-one with treatment and the other without treatment.

$115 \mathrm{Id} . \S 3617$ (c) (3)-(4).

116 H.R. 6915, supra note $2, \S 6122(\mathrm{e})(3)(\mathrm{D})$.

117 Id. $\$ 6122(\mathrm{e})(3)(\mathrm{F})$.

118 Often, psychiatrists and psychologists have no special training or experience in the legal question of competency. See, e.g., Gunther v. United States, 215 F.2d 493, 496-97 (D.C. Cir. 1954); Leavy, The Mentally IIl Criminal Defendant, 9 CRIM. L. BuLl 197, 220-21 (1973); Mental 
hand, is not as demanding in the type of information that must be provided in the report to the court and is not as specific as to the nature.of the medical conclusions that should be supplied to the court. The Senate bill instead relies more heavily on the examiner's opinion as to the mental incompetence of a defendant. Both bills, however, represent an improvement over existing federal law, ${ }^{119}$ which has no content requirements for the psychiatric report, in their attempts to structure the type of evidence that a court should have available in determining competency to stand trial.

\section{Fifth Amendment Problems and the Exclusion of Evidence Obtained During the Mental Competency Examination}

Like the provisions of title $18,{ }^{120}$ S. $1722^{121}$ and H.R. $6915^{122}$ prohibit the admissibility of statements made by a defendant during the course of a psychiatric examination when offered on the issue of guilt. These exclusionary provisions are designed to avoid compelling a defendant in a court-ordered psychiatric examination to incriminate himself. ${ }^{123}$ The defendant's compelled statements, ${ }^{124}$ it is assumed, will not

Health Law Project, supra note 8, at 621-24. In Gunther, the court concluded that expert psychiatric judgment is relevant on the question of competency to stand trial, but that it is not controlling. "Resolution of this issue requires not only a clinical psychiatric judgment but also a judgment based upon a knowledge of criminal trial proceedings that is peculiarly within the competence of the trial judge." 215 F.2d at 497. See also United States v. Adams, 297 F. Supp. 596, 597-98 (S.D.N.Y. 1969), where, despite the report of a court-appointed psychiatrist that indicated the defendant was a "paranoid schizophrenic" and, therefore, incompetent to stand trial, the court maintained that a mentally ill person was not automatically incompetent to stand trial.

The concern about relegating legal issues to psychiatrists led one circuit court to prohibit psychiatrists from testifying in terms of the legal standard for insanity. Washington v. United States, 390 F.2d 444, 455-57 (D.C. Cir. 1967).

11918 U.S.C. $\S 4244$.

$120 \mathrm{Id}$. This section provides that no statement made by the accused in the course of any examination into his sanity or mental competency "whether the examination shall be with or without the consent of the accused, shall be admitted in evidence against the accused on the issue of guilt in any criminal proceeding." Id.

$121 \mathrm{~S} .1722$, supra note $1, \S 3617(\mathrm{~g})$. The provision reads that "[a] statement made by the defendant during the course of a psychiatric examination . . . is not admissible as evidence against the accused on the issue of guilt in any criminal proceeding." Id.

122 H.R. 6915, supra note $2, \S 6122(\mathrm{e})(4)$. This provision reads as follows:

Any statement or conduct of the defendant occurring during the course of a mental examination or during commitment for treatment . . . or any evidence derived from such statement or conduct-

(A) is not admissible as evidence at any criminal trial of the defendant on the issue of whether the defendant engaged in the conduct constituting the offense charged; and

(B) is admissible at trial on the issues of insanity or state of mind only if the defendant initiates the introduction of such evidence. Id.

123 See, e.g., S. REP. No. 96-553 at 1109; Pizzi, supra note 8, at 43-49.

124 The defendant's statements are compelled in the sense that the court-ordered psychiatric examination in essence requires the defendant to cooperate with the examining psychia- 
incriminate him if his statements are inadmissible on the merits of the crime charged.

The Senate and House bills differ, however, in several respects. First, H.R. 6915 extends the evidentiary prohibition to the defendant's conduct as well as his statements. ${ }^{125}$ Although the defendant's conduct may be nontestimonial, and therefore not within the privilege of the fifth amendment, ${ }^{126}$ the inadmissibility of a defendant's conduct avoids determinations concerning the testimonial nature of the conduct and provides extra protection against an unforeseen use of the psychiatric examination.

Another difference between the two bills lies in the scope of the

trist. A competency examination involves a psychiatric interview concerning the nature of the charges against the defendant in order to provide a basis for an opinion on competency. Competency requires an understanding of the nature of the charges and the ability to assist counsel in his defense, therefore the examiner must ask the defendant about the crime charged. If the defendant refuses to answer the examiner's questions, he does not comply with the court order and subjects himself to the contempt sanction.

Where the defendant's counsel raises the competency issue, a question arises as to whether the defendant is compelled to talk to the examining psychiatrist. Although a defendant's motion for a competency determination may be viewed as a waiver of his right against self-incrimination, there are persuasive reasons for rejecting this position. First, because a waiver of the fifth amendment self-incrimination privilege must be knowing and intelligent, see, e.g., Miranda v. Arizona, 384 U.S. 436 (1966), a defendant's motion to determine his competency indicates a possible lack of competency to waive the fifth amendment privilege as well as to stand trial. Even if the defendant is considered competent to waive this right, his decision to move for a competency determination should not be equated with a knowing and intelligent waiver. Before ordering the competency examination, the court is not required to inform the defendant of his self-incrimination privilege, and nothing suggests such a warning is the regular practice in federal courts. Nor does the psychiatrist have much incentive to give such a warning to the defendant. Second, to require a defendant to waive his fifth amendment privilege as a condition of asserting his due process right to avoid a conviction while incompetent may well impose an impermissible burden on the exercise of a statutory and constitutional right to a competency determination. Finally, and perhaps most importantly, the defense counsel may move for a competency determination without the defendant's participation in the decision. Indeed, counsel for the defendant may have an ethical and constitutional obligation to raise the competency issue over the defendant's objection. See note 20 supra for a discussion of the obligation to raise the competency question. For discussion of the self-incrimination issue, see generally Danforth, Death Knell for Pre-Trial Examination? Privilege Against Self-Incrimination, 19 RuTGERS L. REV. 498 (1965); Lefelt, Pretrial Examinations: Compelled Cooperation and the Fifth Amendment, 10 AM. CRIM. L. ReV. 431 (1972); Pizzi, supra note 8, at 27-34. Note, Requiring a Criminal Defendant to Submit to a Govemment Psychiatric Examination: An Invasion of the Privilege Against Self-Incrimination, 83 HARV. L. REV. 648 (1970).

125 H.R. 6915, supra note $2, \S 6122(\mathrm{e})(4)$. The inclusion of conduct in the provision recognizes the use of conduct as statements in the form of implied assertions. For example, conduct feigning mental incompetency may be viewed as an implied assertion of guilt. Implied assertions by conduct of a defendant would be admissible against him at trial, if not excluded by a provision such as $\S 6122(e)(4)$ in H.R. 6915, because if intended as an assertion, it would be an admission. FED. R. EVID. 801(a), 801(d)(2). If not intended as an assertion, it is not hearsay and thus would be admissible except for a provision like $\S 6122(\mathrm{e})(4)$ in H.R. 6915.

126 See, c.g. , Schmerber v. California, 384 U.S. 757, 760-65 (1966); Lefelt, supra note 124, at 434-35. 
exclusionary provision. The House bill prohibits the use of a defendant's statements or conduct regardless of who is the proponent of the evidence. ${ }^{127}$ The Senate bill, by comparison, excludes the use of such evidence only when offered against the defendant. ${ }^{128}$ There is no prohibition against the defendant's use of this evidence if it is otherwise admissible.

The House bill extends its exclusionary rule to statements or conduct of a defendant during a commitment for treatment to restore competency. ${ }^{129}$ The Senate version excludes only statements of a defendant made during a psychiatric examination. ${ }^{130}$ Because commitment under H.R. 6915 requires a report on the defendant's mental status, ${ }^{131} \mathrm{com}$ mitment for treatment serves much the same purpose as a mental examination prior to the incompetency commitment. The same policy reasons that underlie the exclusion of statements made during the precommitment examination certainly apply to statements made during the commitment evaluation. Both involve compulsion of statements whose use against the defendant implicates the privilege against selfincrimination. The Senate bill similarly contemplates a mental evaluation of a defendant committed for incompetency although the evidentiary prohibition does not extend to a defendant's statements made during such evaluation. For example, the court under the Senate bill is to determine the committed defendant's competency and prognosis for regaining competency after a reasonable period of time, not exceeding four months, and at the end of a reasonable extension. ${ }^{132}$ The court may receive at any time a certificate indicating restoration of competency from the director of the facility in which the defendant is hospitalized. ${ }^{133}$ The reviews of a defendant's incompetency under S. 1722 in essence require the hospital to provide treatment and a continuous evaluation of a defendant's mental state. As both treatment and diagnosis likely may involve psychiatric examinations during commitment, any statements by a defendant during such a commitment should be considered to be compelled, flowing from the involuntary nature of the commitment, and thus should be inadmissible to the same extent as statements made during the pretrial mental examination.

A third difference between the Senate and House bills concerns the

127 H.R. 6915, supra note $2, \S 6122(\mathrm{e})(4)(\mathrm{A})$. See note 122 supra for a restatement of this section.

128 S. 1722, supra note $1, \S 3617(\mathrm{~g})$. See note 121 supra.

129 H.R. 6915, supra note 2, §6122(e)(4). See note 122 supra.

130 S. 1722 , supra note $1, \S 3617(\mathrm{~g})$. See note 121 supra.

131 H.R. 6915, supra note 2, §6124(e)(1)-(3). See text accompanying notes 262-65 infra, for a discussion of this report.

132 S. 1722, supra note $1, \S 3611$ (d). See text accompanying notes 223-24 infra.

133 S. 1722 , supra note $1, \S \S 3611(\mathrm{e}), 3617(\mathrm{e})$. See text accompanying note 225 infra. 
issues on which the defendant's statements or conduct will be inadmissible. The Senate bill, like title 18, excludes the defendant's statements made during a psychiatric examination "on the issue of guilt in any criminal proceeding."134 The House bill, however, renders such evidence inadmissible when offered "on the issue of whether the defendant engaged in the conduct constituting the offense charged."135 Both bills thus do not exclude a defendant's statements during the competency evaluation for all purposes. Only one purpose for which the evidence could be relevant is precluded, so presumably the defendant's statements might be offered on other issues if otherwise admissible. ${ }^{136}$ For example, a defendant's statements offered on the issue of insanity, for impeachment, or at sentencing arguably are used on issues other than guilt. The effect of the difference in the wording of the excluded purpose in both bills is not clear. The language in H.R. 6915 prohibiting the use of a defendant's statements on the issue of whether he engaged in conduct constituting a crime may limit admissibility only when such evidence is offered on the issue of the defendant's commission of the actus reus elements of a crime. This limitation would mean that the exclusionary rule in the House bill is significantly narrower than the Senate version that prohibits such evidence on the issue of guilt, since guilt encompasses both the mens rea and actus reus elements. On the other hand, if the conduct constituting the crime is construed to include both the actus reus, as well as the mental elements of an offense, then both the Senate and House bills exclude the defendant's statements for the same purpose.

Perhaps the major difference between the two bills on this point is the addition of a specific section on admissibility of statements made during the examination in H.R. 6915. Unlike S. 1722, the House bill expressly provides that a defendant's statements or conduct during a competency evaluation is admissible, notwithstanding the exclusionary provision, on the issues of insanity or state of mind, but only if the defendant initiates the introduction of such evidence. ${ }^{137}$ The effect of the exclusionary and admissibility rules in H.R. 6915 is not entirely clear. These provisions are ambiguous in several respects. First, the exclusionary provision prohibits evidence of a defendant's statements or conduct for one purpose only, ${ }^{138}$ yet the admissibility section sets forth only two

134 S. 1722 , supra note $1, \S 3617(\mathrm{~g}) ; 18$ U.S.C. $\S 4244$.

135 H.R. 6915, supra note $2, \S 6122(\mathrm{e})(4)$.

136 The admissibility at trial of the defendant's statements for other purposes would depend on their admissibility under the Federal Rules of Evidence. If admissible for one purpose, the statements may be received in evidence as a general rule even though they are inadmissible for another purpose. See FED. R. EVID. 105.

137 H.R. 6915, supra note $2, \S 6122(\mathrm{e})(4)(B)$. See note 122 supra.

138 H.R. 6915, supra note 2, §6122(e)(4)(A). See note 122 supra. 
admissible purposes. ${ }^{139}$ One possible reading of the two provisions is that evidence of a defendant's statements or conduct during competency evaluations is inadmissible except for two purposes: insanity and mental state. Another equally reasonable interpretation is that such evidence is inadmissible for one purpose - on the issue of whether the defendant engaged in criminal conduct - but that it is admissible for any other relevant purpose. If the relevant purpose is on the issue of insanity or mental state, however, then the introduction of such evidence is conditioned on the defense initiating the introduction. If, however, such evidence is relevant for any purpose other than insanity or mental state, its admissibility is unconditional, and either the prosecutor or the defense could first introduce that evidence. Analysis of the alternative constructions of these provisions in the House bill will demonstrate, however, that neither construction of the bill effectively safeguards a defendant's fifth amendment privilege.

Both the Senate and House bills raise important questions concerning their effectiveness in safeguarding a defendant's fifth amendment privilege against self-incrimination. Focusing first on the Senate bill, S. 1722 provides a use-type immunity in order to effectuate the fifth amendment guarantee. Any compelled statements made by the defendant may not be used against the defendant on the issue of guilt in any criminal proceeding, and thus the defendant is not compelled to be a witness against himself. Use immunity has been sanctioned by the United States Supreme Court as a constitutional substitute for the right to remain silent under the fifth amendment in other contexts. ${ }^{140}$ The problem in the incompetency area is whether the scope of immunity in S. 1722 for statements made during a psychiatric examination is coextensive with the scope of the fifth amendment privilege. In assessing the scope of the S. 1722 immunity, ${ }^{141}$ which is identical to the immunity provided in the present federal incompetency provision, ${ }^{142}$ it is important to compare it with the immunity provision, 18 U.S.C. $\S 6002$, that was upheld by the Supreme Court in Kastigar v. United States. ${ }^{143}$ The immunity statute that was challenged in Kastigar provided that "no testimony or other information compelled under the [court] order (or any information directly or indirectly derived from such testimony or other information) may be used against the witness in any criminal case, except a prosecution for perjury, giving a false statement, or otherwise fail-

139 H.R. 6915, supra note $2, \S 6122(\mathrm{e})(4)(B)$. See note 122 supra.

140 Zicarelli v. New Jersey State Commission of Investigation, 406 U.S. 472 (1972); Kasti-

gar v. United States, 406 U.S. 441 (1972).

141 S. 1722 , supra note $1, \S 3617(\mathrm{~g})$. See note 121 supra.

14218 U.S.C. $\$ 4244$. See note 120 supra.

143406 U.S. 441. 
ing to comply with the order."144 The Supreme Court held that this immunity was coextensive with the scope of the fifth amendment privilege because the immunity statute "prohibits the prosecutorial authorities from using the compelled testimony in any respect . . . ."145

The exclusionary rule in S. 1722, by comparison, does not prohibit the prosecutorial authorities from using the defendant's compelled statements in any respect. Indeed, the Senate provision only prohibits the use of the defendant's statements on the issue of guilt. Although excluding a defendant's statements on the issue of guilt might appear to prohibit the use of such statements in any criminal proceeding and thus be coextensive with the fifth amendment privilege, the issue of guilt language does not necessarily exclude such statements for all purposes in a criminal proceeding. For example, a defendant's statement offered to impeach, or offered on the issue of insanity, or offered at sentencing are arguably used on issues other than guilt. When used for such purposes, however, a defendant's compelled statements would be used in such a way that the defendant is compelled to be a witness against himself. These uses in effect provide less protection than the total use immunity approved by Kastigar; ${ }^{146}$ the immunity provided by S. 1722 thus falls short of the protection necessary to achieve a scope coextensive with the fifth amendment.

The sentencing example provides a striking and current illustration of the limited use immunity in S. 1722 and its ineffectiveness in safeguarding fifth amendment protections. The use at a sentencing hearing of a defendant's statements to a psychiatrist during a court ordered mental examination may be tantamount to compelling a defendant in a criminal case to be a witness against himself. In fact, this issue is presently before the Supreme Court in Estelle v. Smith. ${ }^{147}$ In that case a defendant was ordered by the trial court to submit to a competency examination. Although no statements made by the defendant were offered at the defendant's murder trial, the examining psychiatrist testified for the state on the issue of capital punishment at the sentencing hearing. The United States Court of Appeals for the Fifth Circuit held that the use of the defendant's compelled statements on the issue of pun-

\footnotetext{
14418 U.S.C. $\$ 6002$ (1976), quoled in Kastigar v. United States, 406 U.S. at 448-49.

145406 U.S. at 453 (emphasis in original).

$146 \mathrm{Id}$.
}

147 Smith v. Estelle, 602 F.2d 694 (5th Cir. 1979), cert. granted, 445 U.S. 426 (1980). The questions before the court are (1) whether the capital murder defendant was denied due process by the state's use of psychiatric testimony at the punishment phase of his trial, and (2) whether such a defendant must be advised, prior to the psychiatric examination, of his right to terminate the interview, and right to be asserted by counsel in deciding whether to undergo the examination. See 49 U.S.L.W. 3090 (Aug. 26, 1980). 
ishment violated his fifth amendment right. ${ }^{148}$ In essence, the court found the defendant in Estelle v. Smith was compelled to be a witness against himself on the issue of punishment. The court indicated, however, that such use would be constitutionally sanctioned only if the defendant waived, upon advice of counsel, his right to remain silent during the examination. ${ }^{149}$

Several problems arise in applying the waiver doctrine to compelled mental competence examinations. First, because a waiver of the fifth amendment self-incrimination privilege must be knowing and intelligent, ${ }^{150}$ a court's decision that there is reasonable cause to believe the defendant is incompetent as the basis for the court-ordered examination casts doubt on the competency of the defendant to knowingly and intelligently waive his fifth amendment right. Second, to require the defendant to waive his privilege against self-incrimination as a condition of seeking a competency determination may well impose an impermissible burden on the exercise of the constitutional right to be tried only while competent. ${ }^{151}$ On the other hand, if the defendant objects to a competency inquiry initiated by the prosecutor or the court, the waiver doctrine would effectively preclude a competency determination because competent counsel would likely advise against a waiver. The only alternative for obtaining the information concerning the defendant's mental competency would be to grant the defendant use immunity under 18 U.S.C. $§ 6002$.

In view of the difficulties in establishing a valid waiver in the context of compelled mental examinations, the Smith solution seems unrealistic. A total immunity against the use of a defendant's statements, rather than a waiver doctrine, would be much more effective in safeguarding a defendant's right against self-incrimination. The immunity approach would avoid the problems involved in the application of the waiver doctrine in this context, and it would insure the cooperation of defendants whose mental examination is critical to the competency determination. In summary, if the statements are compelled by court order, the fifth amendment requires the absolute prohibition of the use of such statements against the defendant in any criminal proceeding. ${ }^{152}$ As sentencing is a part of a criminal proceeding, the exclusionary provision of S. 1722 must insure that the defendant's statements "cannot lead to the infliction of criminal penalties on the witness"153 in order to be coex-

148 Smith v. Estelle, 602 F.2d at 708.

149 Id. at 708-09.

150 Miranda v. Arizona, 384 U.S. 436.

151 See note 124 supra.

152 Kastigar v. United States, 406 U.S. 441.

$153 \mathrm{Id}$. at 453. 
tensive with the fifth amendment.

The impeachment example also illustrates the constitutional inadequacy of the limited evidentiary exclusion in S. 1722. The introduction of a defendant's statements for impeachment purposes may be considered to be offered for a purpose other than to establish guilt. In Harris $v$. New York, ${ }^{154}$ the Supreme Court upheld the use of a defendant's statement obtained in violation of Miranda ${ }^{155}$ for impeachment purposes although such statements were inadmissible to establish the defendant's guilt in the prosecution's case in chief. The Court, in affirming the impeachment use of such statements, noted that the trial judge instructed the jury that the statements "could be considered only in passing on petitioner's credibility and not as evidence of guilt."156 Although Harris did not explicitly state that an impeachment use of evidence does not go to the issue of guilt, the Federal Rules of Evidence contemplate that the issues of guilt and credibility are different for purposes of determining the admissibility of prior convictions. ${ }^{157}$ Whatever the value in distinguishing between issues of guilt and credibility in the evidence context, it would seem that the use of a defendant's compelled statements to impeach him is, in essence, the use of his statements against him in a criminal proceeding, and thus a violation of his fifth amendment privilege. Indeed, the Supreme Court, in New Jersey v. Portash, ${ }^{158}$ held that any use of statements compelled pursuant to a use immunity statute is constitutionally proscribed, even for impeachment purposes.

The insanity example further illustrates the definitional problem inherent in S. 1722: What uses of a defendant's statements go to the issue of guilt? Some lower federal courts, under the present federal law, have allowed the use of a defendant's statements made during a competency examination on the insanity issue. The Third Circuit, however, in reviewing such a use, ${ }^{159}$ has rejected the view that the insanity issue is

154401 U.S. 222 (1971).

155 Miranda v. Arizona, 384 U.S. 436.

156 Harris v. New York, 401 U.S. at 223. Cf. Jenkins v. Anderson, 100 S. Ct. 2124 (1980), where the Court upheld the use of a defendant 's pre-arrest silence to impeach his credibility.

157 FED. R. EVID. 404(a) excludes evidence of a person's character or a trait of his character for the purpose of proving that he acted in conformity therewith on a particular occasion. FED. R. Evid. 608, 609, however, permit, subject to certain limitations, the proof of a person's character for truthfulness or untruthfulness to show whether he is credible as a witness. For example, evidence of a defendant's prior felony conviction is inadmissible to prove that the defendant committed the crime with which he is presently charged under rule 404(a), but it may be admissible to impeach the defendant under rule 609 if he testifies and places his credibility as a witness in issue.

158440 U.S. 450 (1979). See also Mincey v. Arizona, 437 U.S. 385 (1978), where the Court held that an involuntary confession, as opposed to one obtained in violation of Miranda, was inadmissible for any purpose.

159 See, e.g., United States v. Alvarez, 519 F.2d 1036 (3d Cir. 1975), where the court was asked to consider if a defendant's statements made to a psychiatrist during a mental compe- 
distinct from the issue of guilt under 18 U.S.C. $\S 4244$, and has stated that when a psychiatrist testifies on the sanity issue, he is testifying against the accused on the issue of guilt. ${ }^{160}$ As the exclusionary provision in S. 1722 is identical to that in 18 U.S.C. $\S 4244$, the problem of determining what is an issue of guilt remains in S. 1722. A complete prohibition on the use of a defendant's compelled statements avoids this problem, and adequately safeguards the fifth amendment privilege.

The Senate bill may be constitutionally suspect in another respect. Unlike the use immunity statute in Kastigar, ${ }^{161}$ the exclusionary provision in S. 1722, like that in 18 U.S.C. $\S 4244$, does not by its terms prohibit the use of evidence derived from a defendant's compelled statements. In United States v. Malcolm, ${ }^{162}$ the Ninth Circuit permitted the use of the fruits of a defendant's statements by allowing a psychiatrist to give his opinion on sanity without disclosing the defendant's statements. The court, in arriving at its decision, relied on the absence of a derivative use prohibition in section 4244 . The court stated that "[i]f the examining psychiatrist does not testify to the statements of the accused, his testimony is not foreclosed by section $4244 . " 163$ The failure of S. 1722 and section 4244 to forbid such derivative evidence may mean that the immunity provided for a defendant's compelled statements is not coextensive with the fifth amendment privilege.

The exclusionary provision in the House bill is similarly inadequate to protect a defendant's privilege against self-incrimination. The use of a defendant's statements is not prohibited if offered at sentencing or to impeach. ${ }^{164}$ The House bill, unlike S. 1722, does exclude the derivative use of a defendant's statements made during the psychiatric evaluation, even if the defendant's statements are excluded. ${ }^{165}$

The provision in H.R. 6915 authorizing the introduction, on the issues of insanity or mental state, of a defendant's statements or conduct made during a court ordered mental evaluation does not present a fifth amendment problem because admissibility is conditioned upon the defendant first introducing such evidence. The introduction of his state-

tency exam were admissible at trial against the defendant on the issue of sanity. The United States District Court for the District of New Jersey in an unreported opinion had allowed the introduction of such statements at the trial.

$160 \mathrm{Id}$. at 1041-45. Cf. Government of the Virgin Islands v. Bellott, 495 F.2d 1393, 1397 (3d Cir. 1974), where the Court of Appeals held that sanity is an issue concerning guilt, and therefore must be proven by the government beyond a reasonable doubt.

161406 U.S. at 448-49, 453. See text accompanying notes 143-45 supra.

162475 F.2d 420 (9th Cir. 1973).

$163 \mathrm{Id}$. at 426.

164 This conclusion depends on the second interpretation of the meaning of $\S 6122(\mathrm{e})(4)(\mathrm{A})$ and $\S 6122(\mathrm{e})(4)(B)$ of H.R. 6915. See text accompanying notes 138-39 supra for the two possible interpretations.

165 H.R. 6915, supra note $2, \S 6122(e)(4)$. See note 122 supra. 
ments or of psychiatric opinions based on his statements, therefore, constitutes a waiver of his right to exclude his compelled statements or derivative information. The waiver would, of course, then allow the government to use such statements in rebuttal.

The House bill, however, does not go far enough. The admissibility provision is limited to the use of a defendant's statements on the issues of insanity and mental state. ${ }^{166}$ If this provision is read with the exclusion provision so as to prohibit such evidence for any other purpose, ${ }^{167} \mathrm{H}$.R. 6915 imposes an unnecessary bar to the admissibility of relevant evidence. Because a concern for a defendant's right against self-incrimination is the basis underlying the inadmissibility rule, ${ }^{168}$ a limitation is not needed on the purposes for which evidence of a defendant's statements may be offered so long as the defendant can waive his fifth amendment right by initiating the introduction of such evidence. If, however, the admissibility and exclusion provisions of H.R. 6915 are construed to permit the introduction of a defendant's compelled statements for any purpose except to prove that the defendant engaged in criminal conduct, ${ }^{169}$ then the condition on admissibility only applies to the use of such evidence for two purposes-insanity and mental state. The use of a defendant's statements or derivative opinions based on his statements would then be admissible at a sentencing proceeding, for example, without the requirement that the defendant first introduce such evidence. Such a use would exceed the scope of immunity that constitutionally supplants a defendant's fifth amendment privilege. ${ }^{170}$

In order to safeguard adequately a defendant's right against selfincrimination in the context of psychiatric evaluations during incompetency proceedings, both S. 1722 and H.R. 6915 need revision. The exclusion provision should prohibit the use against a defendant of his statements or any information derived from his statements in all respects. In addition, the defendant should be able to choose to use such evidence, if otherwise admissible, and thus waive any fifth amendment claim with respect to compelled statements.

The use of the competency examination as a means of developing evidence for a possible insanity defense presents several problems apart from the fifth amendment issue. ${ }^{171}$ First, a defendant may not know that his competency examination includes an evaluation of sanity at the

166 H.R. 6915, supra note $2, \S 6122(e)(4)(B)$.

167 See text accompanying notes $138-39$ supra for the two possible interpretations.

168 See note 123 \& accompanying text supra.

169 See text accompanying notes 138-39 supra for the two possible interpretations of $\S 6122(\mathrm{e})(4)(\mathrm{A})$ and $\S 6122(\mathrm{e})(4)(B)$ of H.R. 6915.

170 See notes $146-53$ \& accompanying text supra.

171 See Pizzi, supra note 8 , at $38-43$, for a full discussion of these problems in the federal courts. 
time of the offense in addition to an evaluation of competency to stand trial. The failure of trial courts to inform the defendant of the dual purposes of the examination has led some appellate courts to impose a notice requirement. ${ }^{172}$ Second, a dual purpose examination is often of longer duration than a competency evaluation by itself, and therefore results in a longer deprivation of liberty for a defendant who is committed to a hospital for the examination. ${ }^{173}$ As few competency evaluations result in insanity defenses, a longer examination and commitment is not justified by necessity. ${ }^{174}$ Finally, the dual purpose examination primarily benefits the prosecutor by serving as a discovery device in anticipation of an insanity defense. ${ }^{175}$ Again, this is an unnecessary use of the competency examination in view of the insanity examination authorized by rule 12.2(c) of the Federal Rules of Criminal Procedure. ${ }^{176}$ Also, the defendant may obtain a psychiatrist of his own choosing for an insanity examination under the Criminal Justice Administration Act. ${ }^{177}$ In view of these criticisms, it is important to ascertain whether the Senate and House bills authorize or prohibit such examinations.

Neither the Senate bill nor the House bill specifically authorizes a dual purpose examination when the court orders a mental examination on competency. ${ }^{178}$ By the same token, neither specifically prohibits a simultaneous examination on sanity at the time of the competency examination. The reasonable construction of the provisions concerning the court order for a competency evaluation and the requirements of the examiner's report suggest that both bills contemplate only a single purpose examination-to determine competency. The Senate bill, for example, requires that a mental examination report include the examiner's opinions concerning the defendant's competency. ${ }^{179}$ In addi-

172 See, e.g., United States v. Driscoll, 399 F.2d 135 (2d Cir. 1968).

173 See Pizzi, supra note 8, at 41.

174 Id.

$175 \mathrm{Id}$. at 40.

176 FED. R. CRIM. P. 12.2(a) mandates that, if a defendant is going to rely upon the insanity defense, he must notify the government in writing of such an intention. Under FED. R. CRIM. P. 12.2(c), then, the court is empowered, upon the government's motion, to "order the defendant to submit to a psychiatric examination by a psychiatrist designated for this purpose in the order of the court."

17718 U.S.C. $\S 3006 \mathrm{~A}(1980)$. The specific provision whereby a defendant can obtain his own psychiatrist is $\S 3006 \mathrm{~A}(\mathrm{e})(1)$.

178 Although 18 U.S.C. $\S 4244$ also does not explicitly authorize a dual purpose examination, federal district courts often include an order for an insanity examination in the order for a competency examination. Such orders for dual purpose examinations have been upheld on the basis of the inherent power of the court; any authority stemming from 18 U.S.C. $\S 4244$ for such orders has been rejected. See, e.g., United States v. Jines, 536 F.2d 1255, 1256 (8th Cir.), cert. denied, 429 U.S. 942 (1976); United States v. Wade, 489 F.2d 258, 259 (9th Cir. 1973); Pizzi, supra note 8, at 38-41.

179 S. 1722, supra note $1, \S 3617$ (c)(4)(A). 
tion, it provides for a separate psychiatric examination on the issue of insanity, ${ }^{180}$ and the report of an insanity examination must include opinions concerning the defendant's sanity at the time of the offense charged. ${ }^{181}$ Two separate examinations are thus contemplated under $\mathrm{S}$. 1722; the competency examination is not designed to serve both purposes. Although the House bill includes no provision concerning the determination of the existence of insanity at the time of the offense, the competency provisions clearly state that the examination ordered is to determine the competency of the defendant. ${ }^{182}$

A related evidentiary exclusion in S. 1722 again follows the existing law in 18 U.S.C. $\S 4244$. This provision states that "[a] finding by the court that the defendant is mentally incompetent to stand trial shall not prejudice the defendant in raising the issue of his insanity as a defense to the offense charged, and shall not be admissible as evidence in a trial for the offense charged."183 There is no like provision in the House bill. This exclusion is consistent with the Federal Rules of Evidence which would treat the finding of present incompetency as hearsay ${ }^{184}$ and as irrelevant to the question of insanity at the time of the commission of the offense and also irrelevant to the question of guilt or innocence. ${ }^{185}$

\section{Hearing to Determine Competency}

Time Limits. There is no time limit within which the competency hearing must be held under the Senate bill. The only time constraints imposed by S. 1722 are those provided for the mental examination. ${ }^{186}$ Delays between the termination of the competency examination and the filing of the report and between the receipt of the report and the hearing are not limited by specific statutory time periods. In this respect, $\mathrm{S}$. 1722 is similar to 18 U.S.C. $\S 4244 .{ }^{187}$

The House bill strictly circumscribes the time period within which the competency hearing may be held. In addition to the limit on the

$180 \mathrm{Id} . \S \S 3612(\mathrm{a}), 3617$ (c) (4)(B).

181 Id. $\S 3617$ (c)(4)(B).

182 H.R. 6915 , supra note $2, \S 6122$ (c).

183 S. 1722, supra note $1, \S 3611(\mathrm{f})$.

184 See FED. R. Evid. 801 (c). The testimony would be inadmissible as to the truth of the asserted insanity.

185 A finding of incompetency would not have any tendency to make the existence of the defendant's guilt or innocence more or less probable than it would be without such evidence. See FED. R. EvID. 401, 402. Likewise, a finding of present incompetency would have little or no probative value on the issue of insanity at the time of the commission of the offense. Incompetency relates to a different time than insanity, and the tests for incompetency and insanity are quite different.

186 S. 1722, supra note $1, \S 3617$ (b).

18718 U.S.C. § 4244. 
time for filling the psychiatric report with the court, ${ }^{188}$ H.R. 6915 requires that the competency hearing commence no later than ten days after the receipt of the report unless the defendant requests an additional examination by a mental health examiner of the defendant's choice. ${ }^{189}$ Such a request requires the postponement of the hearing for fifteen days and the mandatory appointment of the defendant's choice of examiner. ${ }^{190}$

Procedural Safeguards. At the competency hearing ordered pursuant to the Senate bill, a defendant is entitled to a number of procedural due process rights. The existing federal statute, by contrast, does not expressly include any hearing rights. ${ }^{191}$ Included in the protections afforded a defendant in S. 1722 are the right to counsel at the hearing, including appointed counsel, the opportunity to testify, to present evidence, to subpoena witnesses, and to confront and crossexamine witnesses. ${ }^{192}$ The House bill provides for the same rights except for the right to counsel. ${ }^{193}$ The failure to include this right may not be important if the defendant is entitled to counsel under the sixth and fourteenth amendments to the Constitution. The right to counsel, however, does not necessarily exist for all criminal defendants. Misdemeanor defendants who are not sentenced to a term of imprisonment do not have a right to the assistance of counsel as a constitutional requirement. ${ }^{194}$ But as a misdemeanor defendant who is found incompetent to stand trial may be committed involuntarily to a mental institution, such a commitment hearing should afford the assistance of counsel as a matter of due process. ${ }^{195}$ The failure of H.R. 6915 to explicitly provide for counsel at

188 H.R. 6915, supra note $2, \S 6122(\mathrm{e})(2)$.

189 Id. $\S 6123(\mathrm{a})(2)$.

$190 \mathrm{ld}$. $\S 6123(\mathrm{a})(3)$.

19118 U.S.C. § 4244.

192 S. 1722 , supra note $1, \S 3617$ (d).

193 H.R. 6915 , supra note $2, \S 6123$ (a)(4). This section provides that, at the hearing, the defendant shall have the right to present evidence, subpoena witnesses, and cross-examine adverse witnesses.

194 Scott v. Illinois, 440 U.S. 367, 373-74 (1979).

195 For an adult, involuntary commitment to a mental institution for an indefinite period of time requires due process protection, such as a commitment hearing, regardless of whether the person is an ordinary citizen or a person charged with a crime. Addington v. Texas, 441 U.S. 418, 425 (1979); Jackson v. Indiana, 406 U.S. at 738. Furthermore, procedural due process rights that attach to such a hearing not only include the opportunity to offer evidence and to cross-examine adverse witnesses, but also include the right to be present with counsel. See Specht v. Patterson, 386 U.S. 605, 610 (1967). The maximum period for which confinement and treatment to regain competency may be ordered is eight months under H.R. 6915, see text accompanying note 231 infra, therefore, because such a period is a defnite period of time, Addington and Jackson may not necessarily require the same protections required for an indefinite period. However, in the recent case of Vitek v. Jones, 445 U.S. 480 (1980), the Court held that a Nebraska statute which authorized the involuntary transfer of a prisoner to 
the competency hearing is not explained in the Report of the House Judiciary Committee. The right to counsel should not be dependent upon whether it is constitutionally required, but rather it should be included as a statutory right based upon the policy reason that a potentially incompetent defendant ought not be left without the assistance of counsel in an adversary proceeding.

Although both the Senate and House bills afford certain procedural rights at the competency hearing, both follow the existing federal caselaw in not providing for a jury determination of competency. ${ }^{196}$ The nature of the competency inquiry as a matter collateral to the adjudication of guilt or innocence and the nature of the commitment as therapeutic rather than punitive do not demand a jury as a constitutional requirement. ${ }^{197}$ Nor do any special policy reasons appear that would dictate a preference for jury rather than court determination of this issue. Indeed, the interest in speedy resolution of this issue-for both speedy trial considerations if the defendant is found to be competent and for treatment considerations if the defendant is found incompetent-would support a non-jury determination. Moreover, the competency determination involves questions of a medical-legal nature that jurors are illsuited to decide.

Standard of Proof. The test for incompetency the court must apply in a hearing under S. 1722 and H.R. 6915 is whether the defendant is presently suffering from a mental disease or defect rendering him mentally incompetent to the extent that he is unable to understand the nature and consequences of the proceedings against him or to assist properly in

a mental institution for treatment without a hearing violated procedural due process and should have provided a full adversarial hearing including the right to be present with counsel. Under the statute in question, if at the expiration of the prison sentence the prisoner was still mentally ill, civil commitment proceedings had to be instituted in order to continue the commitment. 445 U.S. at 483-84. Therefore, the initial commitment of the prisoner constituted a defmite time period in the sense that it could not exceed the duration of the prison sentence without separate civil proceedings commencing. After Vitek, then, a person merely charged with a crime facing the definite commitment period of eight months under H.R. 6915 should not be denied the right to counsel at the competency-commitment hearing outlined in $\$ 6123$. See generally Note, Fourteenth Amendment-Due Process for Prisoners in Commitment Proceedings, $71 \mathrm{~J}$. CRIM. L. \& C. 579 (1980).

196 See, e.g., United States v. Holmes, 452 F.2d 249, 267 (7th Cir. 1971), cert. denied, 405 U.S. 1016, 407 U.S. 909 (1972); Hall v. United States, 410 F.2d 653, 658 (4th Cir.), cert. denied, 396 U.S. 970 (1969); United States v. Huff, 409 F.2d 1225, 1227-28 (5th Cir.), cert. denied, 396 U.S. 857 (1969); United States v. Davis, 365 F.2d 251, 256 (6th Cir. 1966).

197 In Lyles v. United States, 254 F.2d 725 (D.C. Cir. 1957), cert. denied, 356 U.S. 961 (1958), 362 U.S. 943 (1960), 368 U.S. 992 (1962), modified, United States v. Brauner, 471 F.2d 969,997 (1972), the D.C. Circuit stated that competency is a separate issue from the issue of guilt or innocence, and, as such, is an appropriate question only for the judge. "Evidence in respect to this defined competency is not admissible before the jury, because it is not relevant to any question which the jury has to decide." Id. at 730. 
his defense. ${ }^{198}$ This test in essence adopts the standards set forth by the Supreme Court in Dusky v. United States ${ }^{199}$ and included in title $18 .{ }^{200}$

The standard of proof for a determination that a defendant is incompetent to stand trial is one of preponderance of the evidence in both S. $1722^{201}$ and H.R. 6915.202 Although this standard differs from the higher clear and convincing standard that is constitutionally required for civil commitment under Addington $v$. Texas, ${ }^{203}$ the differences between civil commitment and a competency determination justify such a difference in the burden of proof both for constitutional and policy reasons.

The constitutional concern with the standard of proof is to ensure, as a matter of due process, that the factfinder achieves an acceptable degree of confidence in the correctness of factual conclusions for a particular type of adjudication. ${ }^{204}$ The standard thus serves to allocate the risk of an erroneous decision between the litigants and to reflect the relative importance of the decision. ${ }^{205}$ In considering what standard should govern in a civil commitment proceeding, the Supreme Court in Addington $v$. Texas assessed the individual's interest in not being involuntarily confined indefinitely and the state's interest in committing a person. The Supreme Court found that civil commitment impacts significantly on an individual's interest in freedom from detention and the stigma that accompanies civil commitment. ${ }^{206}$ These significant interests call for proof more substantial than a preponderance in order to avoid the risk of an erroneous civil commitment with its consequent injury to the individual. ${ }^{207}$ The state's interests in protecting the community and the individual are not harmed to the same extent by an erroneous decision, and thus the state should assume the risk of an erroneous decision by

198 S. 1722 , supra note $1, \S 3611$ (d); H.R. 6915 , supra note $2, \S 6129(\mathrm{a})(1)$. The test in the House bill is whether the defendant has sufficient present ability "to consult with counsel in the case with a reasonable degree of rational understanding, and otherwise to assist in the defendant's own defense, and to possess a rational and factual understanding of the proceedings against that defendant." Id.

199362 U.S. 402 (1960) (per curiam). The test outlined in Dusky must be whether the defendant " "has sufficient present ability to consult with his lawyer with a reasonable degree of rational understanding - and whether he has a rational as well as factual understanding of the proceedings against him.' "Id.

20018 U.S.C. $\$ 4244$. The standard set forth in the present law is whether the defendant "may be presently insane or otherwise so mentally incompetent as to be unable to understand the proceedings against him or properly to assist in his own defense." Id.

201 S. 1722, supra note $1, \S 3611$ (d). The present law is less specific and provides that the judge is to make a "finding" with respect to evidence presented at the competency hearing in determining the mental competency of the defendant. 18 U.S.C. $\$ 4244$.

202 H.R. 6915, supra note $2, \S 6123$ (b)(1).

203441 U.S. 418.

204 Id. at 423 (citing In re Winship, 397 U.S. 358, 370 (1970) (Harlan, J., concurring)).

$205 \mathrm{Id}$. at 423.

$206 \mathrm{Id}$. at $425-26$.

207 Id. at $426-27$. 
proof more substantial than beyond a preponderance of the evidence. ${ }^{208}$

The factors that led the Court in Addington v. Texas to require a standard higher than a preponderance do not exist in the competency adjudication. First, unlike civil commitment, an incompetency commitment is not an indefinite commitment. ${ }^{209}$ It is a temporary commitment that may not become indefinite without a civil commitment. ${ }^{210}$ Hence, the individual's interests in a competency commitment do not involve the same degree of deprivation of liberty occasioned by civil commitment. In addition, the competency adjudication in H.R. 6915 does not

208 Id. at 427 .

209 See Jackson v. Indiana, 406 U.S. 715, where the court held that a person committed on account of his incapacity to proceed to trial "cannot be held more than the reasonable period of time necessary to determine whether there is a substantial probability that he will attain that capacity in the foreseeable future." Id. at 738. The Court refused, however, to prescribe "arbitrary time limits," preferring, instead, to leave such limits to the discretion of the states. Id. See text accompanying notes 222-24, 242 infra for the limits set out in S. 1722 and H.R. 6915.

210 See notes 228, 247 infra for a description of civil commitment under S. 1722 and H.R. 6915. Under Addington, once the individual faces the possibility of an indefinite civil commitment, the clear and convincing standard of proof becomes applicable. 441 U.S. at 432-33.

Under the Texas civil statutes in Addington, a person could be committed to a mental hospital for an "indefinite period" if (1) he had been under care in a mental hospital for a temporary period of at least 60 days within 12 months of the filing of the petition for an indefinite commitment; and (2) an indefinite commitment hearing was held at which the court or jury found that he was mentally ill and required hospitalization for his own welfare and protection or the protection of others. TEx. REv. Giv. STAT. ANN. arts. 5547-40 to -57 (Vernon 1958 \& Supp. 1980-81). Discharge from indefinite commitment could only occur, first, when the director of the mental hospital determined after examination that the person no longer required hospitalization, in which case the director could discharge the person himself. Id. art. 5547-80(a) (Supp. 1980-81). Secondly, the patient "or his next friend on his behalf' could petition the county court for a re-examination and a hearing to determine the need for continued hospitalization, in which case a hearing would be held without a jury to determine this need; and if the court found that the need for hospitalization had disappeared, then the patient would be discharged. Id. art. 5547-82 (Vernon 1958). The judge was not required to order a re-examination and hearing, however, if the petition was filed within one year of the indefinite commitment order or within two years of the filing of a similar petition. Id. art. 5547-82(g). Thus, the court was not specifically directed to conduct a re-evaluation hearing at regular intervals after the order for indefinite commitment independent of the filing of a discharge petition by the patient.

Many civil commitment statutes, however, now mandate that once a person has been committed to a mental facility for an extended period of time (such as three months or six months), a subsequent re-evaluation hearing is required at a certain time after the initial order, such as six months, before further extended periods of commitment may be ordered. Such hearings are not dependent on the filing of a patient's petition. See, e.g., ILL. ANN. STAT. ch. $911 / 2, \S \S 3-800$ to -813 (Smith-Hurd Supp. 1980-81); N.M. STAT. ANN. $\$ \S 43-1-11$ to -12 (1978); Pa. Stat. Ann. tit. 50, $\$ \S 7304-05$ (Purdon Supp. 1980-81). If a second commitment is then ordered, the process repeats itself so that after a designated time another hearing must be held before a third period of commitment can begin. Id. Under these types of statutes, each commitment period is "definite" in the sense that another period cannot begin until after a hearing has been conducted and a new order entered. These periods, however, are "indefinite" in the sense that a person can only be released from commitment when he meets the standards for release, if ever. 
automatically call for commitment. Rather than requiring commitment for treatment in all cases, like S. 1722, ${ }^{211}$ the House bill permits either outpatient treatment or hospitalized commitment upon a finding of incompetence. ${ }^{212}$ The House bill requires a separate decision to commit a defendant for treatment, and this determination is the subject of a separate commitment hearing. ${ }^{213}$ Second, and more important, the interest of a defendant in the competency proceeding is not always against a determination of incompetency. A defendant often seeks a finding of incompetency that is opposed by the government. ${ }^{214}$ On the other hand, in some cases the court or the prosecutor raises the issue of competency, ${ }^{215}$ and the defendant opposes a finding of incompetency. Where defendants' interests as a group are unclear or contradictory, it is difficult, if not impossible, to assess the impact of an erroneous decision in the abstract. Of course, it may be possible to provide for two different standards of proof depending upon who initiates the competency proceeding. For example, the preponderance standard might be used when the defendant moves to establish his incompetency. The state's interests would not then be sufficient to require a greater standard than preponderance of the evidence. ${ }^{216}$ If, however, the court or the attorney for the government attempts to have the defendant declared incompetent, the interests of such a defendant would be much the same as those of the civil commitment individual, and a standard of clear and convincing proof might be constitutionally required under the reasoning of $A d d i n g-$ ton v. Texas. ${ }^{217}$

A third reason, however, suggests that a preponderance standard is more appropriate and constitutional than the clear and convincing stan-

211 S. 1722 , supra note $1, \S 3611$ (d). This section requires commitment and does not authorize outpatient treatment for the incompetent defendant.

212 H.R. 6915, supra note 2, § 6124(b).

213 Id. $\S \S 6123(\mathrm{~b})(2), 6123$ (c) (2). See text accompanying notes 242-68 infra for a full discussion of the separate commitment hearing in H.R. 6915.

214 Section 3611 (a) of S. 1722 and $\S 6121$ (b)(1) of H.R. 6915 permit the defendant to raise the competency issue. See notes 19-20 \& accompaying text supra for a discussion of who may raise the issue.

One District of Columbia study, in fact, found that from fiscal 1952 through fiscal 1963, $85.7 \%$ of the motions requesting pretrial mental examinations of the defendant for the competency inquiry were filed by the defense. Judicial CONFERENCE of THE District of Columbia Circuit, Report of the Committee on Problems Connected with Mental Examination of THe Accused in CRiminal Cases 24 (1965), cited in Pizzi, supra note 8, at 22 nn.10-11.

215 Section 3611 (a) of S. 1722 and $\S \S 6121$ (b)(1)-(2) of H.R. 6915 also permit the government attorney or the court to raise the competency issue. See notes 19-20 \& accompanying text supra.

216 In the view of the House Judiciary Committee, for example, it would be inappropriate to require a higher standard than the preponderance of the evidence "as a protection for the defendant when the defendant is making the motion." H.R. REP. No. 96-1396 at 554.

217441 U.S. at $423-33$. 
dard. A significant factor in imposing the higher standard in Addington was the nature of the state interests in civil commitment. These interests were considered insufficient to outweigh the individual interests that were harmed by an erroneous commitment decision. In a competency proceeding, including one in which the litigants are in the position similar to the litigants in civil commitment-the state is the moving party and the defendant is opposing - the state's interest includes the constitutional concern that an incompetent defendant not be convicted. ${ }^{218}$ This due process interest may be so important that the opposing defendant's interests in liberty and in avoiding the stigma of commitment do not outweigh the harm to the state and to the adversary system in convicting an incompetent defendant so that an erroneous determination of incompetence involves as much harm to the state as to the defendant. In other words, in a competency proceeding the defendant may be asked to share equally with the state the risk of error when the possible injury to the defendant is not significantly greater than the possible harm to the state. Thus, only proof of incompetency by a preponderance of the evidence will be constitutionally required. ${ }^{219}$

\section{Dispositions Following the Competency Hearing}

If the court does not find by a preponderance of the evidence that a defendant is incompetent to stand trial, the trial of the case shall proceed. ${ }^{220}$ If, however, the court finds by a preponderance that a defend-

218 See Drope v. Missouri, 420 U.S. at 171-72; Pate v. Robinson, 383 U.S. at 378.

219 In Jackson v. Indiana, 406 U.S. at 725, furthermore, the Court indicated that lesser safeguards may be appropriate where the commitment is temporary-as in a competency commitment under S. 1722 and H.R. 6915. Therefore, the clear and convincing standard of proof under Addington is not necessarily a constitutional requirement for a competency hearing. In addition, because the state interest in discovering incompetency is so crucial to due process, and because the lower preponderance of the evidence standard would further that interest more readily than the clear and convincing standard, the preponderance standard appears to be the constitutionally-mandated standard. But see Pizzi, supra note 8, at 65-66, where the commentator attacks the preponderance standard which is prescribed in S. 1722 and H.R. 6915. Any statutory provision which incorporates such a standard, for Pizzi, "misconceives the responsibility of the trial court. It will permit the court to try a defendant even if the court, after having heard the evidence, remains uncertain as to the defendant's competency." Id. at 66. Pizzi suggests, instead, that the court conduct and control a thorough hearing into the issue of competency, without relying on adversarial procedures such as crossexamination and burdens of proof, in order to assure itself of the competency of the defendant before proceeding to trial. Id. at 63-64, 66 .

220 H.R. 6915, supra note $2, \S 6123$ (b)(1). Section 3611 (d) of S. 1722 does not specifically state that the case shall proceed to trial upon such a finding. However, in $\S 3611$ (e) of S. 1722 , it is stated that a defendant who has recovered his competency during his competency commitment shall then have his "date for trial" set by the court. S. 1722, supra note 1, $\S 3611$ (e). See note 226 \& accompanying text infra. By implication, therefore, the court shall likewise set a trial date if the defendant is found competent at the initial competency hearing. 
ant is incompetent to stand trial, the Senate and House versions prescribe different alternatives.

\section{A. DISPOSITION PROCEDURES UNDER THE SENATE BILL}

The Senate bill mandates commitment of an incompetent defendant to a mental hospital for treatment. ${ }^{221}$ No alternative to commitment is prescribed. Commitment of an incompetent defendant is limited to a reasonable period, not to exceed four months, as is necessary to determine whether there is a substantial probability that in the foreseeable future he will attain the capacity to stand trial. ${ }^{222}$ This duration of the commitment is consistent with the requirements set forth by the Supreme Court in Jackson v. Indiana. ${ }^{223}$ A reasonable extension, not to exceed two months, is permitted if the court finds a substantial probability that during such an extension he will regain the competency to stand trial. ${ }^{224}$ At any time that a defendant's mental condition is so improved that the trial may proceed, the director of the hospital must file a certificate to that effect with the clerk of the court that ordered the commitment. ${ }^{225}$ The court shall then hold a hearing to determine the defendant's competency to stand trial. If the court finds the defendant to be competent by a preponderance of the evidence, the court must order the release of the defendant from the hospital and set the case for trial. ${ }^{226}$ In addition, the defendant must be released from the hospital whenever the pending criminal charges are disposed of according to law. ${ }^{227}$

221 S. 1722, supra note $1, \S 3611(\mathrm{~d})$.

222 Id. $\S 3611$ (d)(1).

223406 U.S. 715. See note 209 supra for the holding. The Court added, however, that if it is determined during or at the end of the reasonable commitment period that there is no substantial probability that the defendant will attain competency in the foreseeable future, then state civil commitment procedures must be instituted, or the defendant must be released. 406 U.S. at 738 . See note 228 infra for a description of the civil commitment process under S. 1722.

224 S. 1722, supra note $1, \S 3611$ (d)(2)(A).

225 Id. $\S 3611$ (e).

226 Id. At this later hearing, in contrast to the initital competency hearing, the court must find that the preponderance of the evidence indicates compelency instead of incompetency.

227 Id. $\S 3611$ (d)(2)(B). The present law is much less specific on the duration of confinement and provides merely that "the court may commit the accused to the custody of the Attorney General or his authorized representative, until the accused shall be mentally competent to stand trial or until the pending charges against him are disposed of according to law." 18 U.S.C. $\$ 4246$. However, the courts have interpreted this competency confinement as a temporary one that may not become indefinite without a finding that the defendant's release "will probably endanger the safety of the officers, the property, or other interests of the United States" as provided for in 18 U.S.C. $\$ 4247$. See, e.g. , United States v. Wood, 469 F.2d 676, 676-77 (5th Cir. 1972) (per curiam); United States v. Curry, 410 F.2d 1372, 1374 (4th Cir. 1969); Royal v. Settle, 192 F. Supp. 176, 178 (W.D. Mo. 1959). See note 228 infra for a discussion of indefinite commitment under the present federal law. 
If a defendant is still incompetent to stand trial at the end of the maximum commitment, the Senate bill, like the present federal law, provides that the defendant is subject to procedures that may lead to civil commitment by state authorities or by the federal government. ${ }^{228}$ Pending these procedures, the defendant may be detained at the hospi-

228 S. 1722, supra note $1, \S \S 3611$ (d), 3161 . Section 3616 governs the disposition of one who is still determined to be mentally incompetent at the end of the four-month period or the twomonth extension. If the director of the facility in which the defendant is being treated certifies that the defendant is presently suffering from a mental disease or defect as a result of which his release would create "a substantial risk of serious bodily injury to another person or serious damage to property of another," and that arrangements for the commencement of state civil commitment procedures are not available, then the director shall transmit the certificate to the court and the court shall hold a hearing to determine by clear and convincing evidence if the defendant's release would, in fact, create the substantial risks outlined by the director. Id. $\S 3616($ a). The court may order that a psychiatric exam be conducted and that a report be filed with the court prior to the hearing. Id. \$ 3616(b). The hearing is to incorporate all the procedural safeguards provided for the competency hearing in $\$ 3611$ (d). Id. $\$ 3616$ (c). See text accompanying note 192 supra. The clear and convincing standard of proof is applied, as under Addington, because the court is asked to determine the dangerousness of the defendant, not the competency, and because of the potential for an indefinite commitment based on dangerousness. Once the finding of dangerousness is made by the court, the Attorney General shall release the person to the state in which he was domiciled or was tried; but if such state will not assume responsibility, the person is to be, in effect, civilly committed for treatment in a suitable facility until such a state will assume responsibility or unit his release or conditional release under a prescribed regimen of medical care will no longer create the "substantial risks" which triggered the commitment. Id. \$3616(d). The director of the facility is to communicate to the court when the person no longer presents the risks to persons and property, and the court shall discharge the person or hold a hearing on its own motion or on the government's motion. Id. $\$ 3616(\mathrm{e})$. At this hearing the level of proof changes, so that the court must find by a preponderance of the evidence that release or conditional release would no longer create a substantial risk to persons or property before discharging the person. Id. However, the person may always challenge the legality of his detention by a writ of habeas corpus. Id. $\S 3617(\mathrm{~h})$. Also, $\$ 3617$ (i) provides that the person's counsel or legal guardian may at any time during the hospitalization of the person file with the court a motion for a hearing to determine if discharge from the mental health facility is warranted, although no such motion may be filed within 180 days of a court determination that continued hospitalization is required.

Present federal law also provides for a hearing to determine dangerousness although dangerousness is defined in terms of endangering "the safety of the officers, the property, or other interests of the United States;" and the hearing does not specifically provide the defendant with counsel, nor allow him to testify, although "the court may in its discretion call any other witnesses for the prisoner." 18 U.S.C. $\S 4247$. Such a hearing is triggered when the director of a facility to which a defendant has been committed because of incompetence to stand trial, under 18 U.S.C. $\S 4246$, certifies to the court that the defendant is dangerous as defined and that suitable arrangements for his care and custody are not otherwise available. The court must, upon receipt of the certificate, cause the defendant to be examined by a psychiatrist designated by the court and one selected by the defendant prior to the hearing. See note 227 supra. Under 18 U.S.C. $\$ 4247$, the court is to determine if the dangerousness exists after hearing the evidence (no level of proof is specified), and if the court finds the defendant dangerous, the Attorney General shall commit the defendant for treatment until the defendant no longer is dangerous, or until arrangements have been made for the care and custody of the defendant in the state of his residence or until his competency is restored, whichever is 
tal to which he was committed. ${ }^{229}$

No provision in the Senate bill, or in the present federal law, addresses the question of what happens to the criminal charges if at the end of the maximum commitment the defendant is still incompetent to stand trial. The holding in Jackson $v$. Indiana ${ }^{230}$ addressed only the constitutional limitations on an incompetency commitment. ${ }^{231}$ The Supreme Court was asked to dismiss the charges against the petitioner who the Court found would likely never be able to participate fully in a trial. ${ }^{232}$ The Court declined to consider the issue, stating:

Dismissal of charges against an incompetent accused has usually been thought to be justified on grounds not squarely presented here: particularly, the Sixth-Fourteenth Amendment right to a speedy trial, or the denial of due process inherent in holding pending charges indefinitely over the head of one who will never have a chance to prove his innocence. Jackson did not present the Sixth-Fourteenth Amendment issue to the state courts. Nor did the highest state court rule on the due process issue, if indeed it was presented to that court in precisely the above-described form. We think . . . that the Indiana courts should have the first opportunity to determine these issues. ${ }^{233}$

Several federal courts after Jackson have dismissed the criminal charges against a defendant who was incompetent to stand trial. ${ }^{234}$ In United States v. Geelan, ${ }^{235}$ the Ninth Circuit relied on the sixth amendment right to a speedy trial in dismissing the indictment. The court, applying the test in Barker 0 . Wingo, ${ }^{236}$ found that the delay of over six

earliest. 18 U.S.C. $\S 4248$. As with S. 1722, habeas corpus is provided in 18 U.S.C. $\S 4248$ as a method of challenging any commitment.

In construing 18 U.S.C. $\$ \S 4246-48$, the Supreme Court held that it is appropriate for a court to hold a "dangerousness" hearing under $\S 4247$ for one committed because of incompetency under $\S 4246$, once it is determined by a director of a facility that the mental incompetence seems more than temporary. Greenwood v. United States, 350 U.S. 366, 374 (1956). The Court held, furthermore, that the possibility of indefinite commitment under $\$ 4248$, based on the findings in $\S 4247$, is constitutionally permissible even though there may be little likelihood of recovery. Id. at 375. After Jackson v. Indiana, 406 U.S. 715, the duration of the competency commitment under $\S 4246$ has been strictly limited to such time as is necessary to determine whether there is a substantial chance of the defendant attaining competency in the foreseeable future. E.g, United States v. Wood, 469 F.2d at 676-77. If, however, chances are slight or there is no improvement in the defendant's condition, "then he must be released or granted a hearing pursuant to 18 U.S.C. $\S 4247$." Id. at 677 . The $\S 4247$ hearing would then serve as the basis for the possible indefinite commitment under $\$ 4248$.

229 S. 1722, supra note $1, \S 3616$ (a). No time limit is prescribed for this detention pending the completion of the civil commitment procedures, as described in note 228 supra.

230406 U.S. 715.

231 See notes 209, 223 \& accompanying text supra.

232406 U.S. at 738-39.

$233 \mathrm{Id}$. at 740 (footnotes omitted).

234 See, e.g., United States v. Geelan, 520 F.2d 585 (9th Cir. 1975); United States v. Pardue, 354 F. Supp. 1377 (D. Conn. 1973).

235520 F.2d 585.

236407 U.S. 514. See note 103 supra for a discussion of the balancing test in Barker. 
years, due to an incompetency commitment in a mental hospital resulted in severe prejudice to his insanity defense and denied him his right to a speedy trial. 237 In United States v. Pardue, ${ }^{238}$ the court stated that due to the defendant's incompetency detention of nearly three years and the small likelihood of his restoration to competency, " $[\mathrm{h}]$ is right to a speedy trial is now in jeopardy, and serious questions of due process and cruel and unusual punishment are present." 239 The court then ordered the release of the defendant and dismissed the indictment without specifying which of the constitutional concerns was determinative.

Jackson does not mandate dismissal of the indictment at the end of the maximum treatment period so the charges pend against the incompetent defendant. Jackson and S. 1722 require only the initiation of civil commitment proceedings or the release of such a defendant at the end of the maximum incompetency commitment. ${ }^{240}$ The indictment may therefore hang over the defendant's head while civilly committed or after his release. The only limits on the duration of this status for a defendant are the sixth amendment right to speedy trial and perhaps the due process clause. Neither the Speedy Trial Act of $1974^{241}$ nor S. 1722 provide a statutory solution to this problem.

\section{B. DISPOSITION PROCEDURES UNDER THE HOUSE BILL}

\section{Treatment Determination}

The House bill is superior to the Senate version because commitment does not automatically follow a court's finding under H.R. 6915 that a defendant is incompetent to stand trial. This determination requires an immediate treatment hearing to determine whether there is a substantial probability that the defendant can be restored to competence within the maximum period (eight months) for which treatment may be ordered, and, if so, what treatment is most appropriate to effect that restoration. ${ }^{242}$ If the court determines there is no substantial

237 United States v. Geelan, 520 F.2d at 588-89.

238354 F. Supp. 1377.

239 Id. at 1382 . The court did not, however, specifically find that there was a speedy trial, due process, or cruel and unusual punishment violation. Rather, the court seemed to base its decision for releasing the defendant and dismissing the charges on the fact that the incompetency commitment under 18 U.S.C. $\$ \S 4244-48$ had surpassed a "reasonable period of time" especially since it was not foreseeable when he would be competent to stand trial, and because there was no appropriate federal facility at which he could receive the care he needed. $354 \mathrm{~F}$. Supp. at 1381-82. See notes 227-28 supra for a discussion of procedure under 18 U.S.C. $\S \S 4244-48$.

240406 U.S. at 738; S. 1722, supra note 1 , §§ 3611 (d), 3616.

24118 U.S.C. $\S \S 3161-74$ (1976 \& Supp. IV 1980). The Act specifically exempts delay due to incompetency for purposes of determining violations of the Act in $\S 3161(\mathrm{~h})(1)(\mathrm{A})$ and $\S 3161(\mathrm{~h})(4)$. See note 103 supra for a brief discussion of the Act.

242 H.R. 6915, supra note 2, §6123(b)(2)(A)-(B). 
probability that the defendant can be restored to competency, and the defendant does not request treatment, the court must order the defendant released and dismiss all charges except class A or B felonies. ${ }^{243} \mathrm{Un}$ like S. 1722, the House bill sets forth procedures for disposing of some criminal charges against an incompetent defendant. ${ }^{244}$ If the charges are not of the most serious grade, they will be dismissed. Only class A and $\mathrm{B}$ felonies, the most serious and most severely punished, will pend, but only until the delay before trial amounts to a sixth amendment speedy trial violation or a fifth amendment due process violation. ${ }^{245}$

The effect of the treatment hearing is to avoid commitment and treatment of an incompetent defendant for whom treatment is unwanted and is inefficacious for purposes of restoring competency. ${ }^{246}$ Such a defendant is then immediately subject to procedures that may lead to delivery of the defendant to appropriate state officials for possible commencement of civil commitment proceedings by the state. ${ }^{247} \mathrm{~A}$ dismissal of the federal criminal charges by reason of the defendant's incompetence may be delayed pending delivery of the defendant to state authorities. ${ }^{248}$ If, therefore, a defendant regains competency to stand trial pending such delivery, criminal proceedings may resume. ${ }^{249}$

If the court determines at the treatment hearing there is a substantial probability of restoring the defendant's competence, the court must

243 Id. $\$ 6123(\mathrm{c})(1)$. H.R. 6915 defines class A and B felonies for purposes of authorized terms of imprisonment as follows: for a class A felony, one can be imprisoned "not more than life;" for a class B felony "not more than 160 months." Id. § 3702 . The House bill and the House Report do not indicate when, if ever, such charges will be dismissed against a defendant. Presumably, then, the charges could stand until the death of an incompetent defendant.

244 See notes 230-41 \& accompanying text supra for a discussion of S. 1722 and the uncertainty as to the dismissal of criminal charges after the maximum period for the incompetency commitment.

245 See notes 103, 233-41 \& accompanying text supra.

246 See H.R. REP. No. $96-1396$ at 554-55.

247 H.R. 6915, supra note 2, $\S$ 6123(c)(1), 6125(a). Section 6125(a) of H.R. 6915 provides that a person found incompetent with no substantial probability of improvement shall be delivered to the appropriate state officials in the state of the person's domicile, or, if there is no domicile, in the state in which the federal court sits for possible commencement of state civil commitment procedures if the court determines "there is probable cause to believe that such person is presently suffering from mental disease or defect as a result of which such person's release would create a substantial likelihood of serious injury to any person or substantial damage to property of others." Id. $\S 6125(\mathrm{a})$, This section provides no alternate procedure should the states refuse custody of the person, and is, therefore, different in scope than S. 1722 and the present law. See note 228 supra. According to the House Report, the House Judiciary Committee rejected the continuation of the federal procedure for commitment of those found incompetent to stand trial and also dangerous. H.R. REP. No. 96-1396 at 559. The committee basically concluded that such a procedure was an unconstitutional extension of federal power into an area traditionally left to the states, and, in the long run, could only lead to heavier federal involvement in the care of the mentally ill. Id. at 559-61.

248 H.R. 6915, supra note 2, §6125(b).

249 Id. 
order treatment for the defendant. ${ }^{250}$ The House bill, however, gives the court discretion to avoid treatment, dismiss the charges, and subject the defendant to the procedures for delivery to state officials for civil commitment. ${ }^{251}$ The exercise of this discretion requires the court to find that the defendant opposes treatment and that to require involuntary treatment would be unduly oppressive in the light of five factors: the probability that treatment will restore the defendant to competence, the nature of the proposed treatment, the nature of the charges, any weaknesses in the government's case, and the probable sentence to be imposed if the defendant is convicted. ${ }^{252}$ The discretion to dismiss the charges even when treatment may restore competency is a significant power given to the court. Properly exercised, this discretion will permit the court to dismiss criminal charges for which the maximum sentence is one year or less, or those charges for which it is likely that upon conviction the court will order probation or impose a sentence less than the maximum time for treatment to restore competency. In essence, this discretionary provision allows the court to avoid treatment for competency that may be more of an imposition on a defendant than serving a sentence upon conviction. In addition, this discretionary power may prevent the abuse of incompetency proceedings by the government. Although the attorney for the government may initiate the competency issue over the defendant's objection, ${ }^{253}$ a determination of incompetency and that it is treatable does not necessarily mean that a defendant may be involuntarily committed or treated if the court finds that such treatment will be unduly oppressive. ${ }^{254}$ In other words, the government cannot under H.R. 6915 use a commitment for treatment of incompetency as an alternative to criminal prosecution and conviction if the court finds such an alternative to be unduly oppressive.

\section{Commitment Determination}

The decision to order treatment under H.R. 6915 requires the court to specify the facility at which the defendant is to be treated.255 Significantly, the order to treat does not automatically mean commitment to the treatment facility. H.R. 6915 provides that the defendant to be treated may not be required to reside in or be confined at the specified facility unless the court makes specific findings of fact supporting one of

250 Id. $\S 6123(\mathrm{c})(2)$.

251 Id.

252 Id. $\S 6123(\mathrm{c})(2)(\mathrm{A})-(\mathrm{B})$.

$253 \mathrm{Id} . \S 6121(\mathrm{~b})(1)$.

254 See H.R. REP. No. $96-1396$ at 554.

255 H.R. 6915, supra note 2, §6124(a). 
four conclusions indicating that confinement is necessary. ${ }^{256}$ The four conditions essential for commitment for treatment of an incompetent defendant are: (1) Such residence or confinement is necessary for such treatment; (2) Such residence or confinement is necessary because the defendant has failed to appear for such treatment or similar treatment in the past; (3) The defendant presents a substantial probability of serious bodily injury to any person or substantial damage to property of others; or (4) The defendant is not otherwise released from pretrial commitment. ${ }^{257}$

The commitment provisions of H.R. 6915 thus create a presumption of treatment at a facility on an outpatient basis for defendants who are able to make bail. The defendant has not been convicted of a criminal offense, so there is no reason to involuntarily commit a defendant and deprive him of his liberty prior to trial absent a showing of medical necessity, dangerousness, or likelihood of failure to appear for treatment. ${ }^{258}$ In summary, the procedure to be followed after a finding of incompetency requires a hearing at which the court must decide whether to order treatment for the incompetent defendant. If treatment is to be ordered, the court must then decide whether to commit the incompetent person for treatment. ${ }^{259}$

Although the maximum period of treatment as an outpatient or while confined is 240 days under H.R. $6915,{ }^{260}$ no specific provision allows the order for treatment to specify a shorter time period. The bill provides only that the court make an appropriate order. ${ }^{261}$ This provision may contemplate a time limit in the order. But even without a specified time period in the treatment order, a report to the court by the person in charge of the facility in which the defendant is being treated will automatically call for a redetermination of competency or the need for additional treatment by the court. ${ }^{262}$ A report to the court is required 110 days after the first order of treatment; ${ }^{263}$ and if the court

256 Id. $\S 6124(\mathrm{~b})$.

$257 \mathrm{Id}$.

258 See H.R. REP. No. 96-1396 at 555.

259 Although no separate hearing is prescribed for this commitment determination, the decision to commit presumably would be part of the treatment hearing authorized under $\S 6123(\mathrm{~b})(2)$. See text accompanying note 231 stpra.

260 H.R. 6915, supra note $2, \S 6123$ (c)(1)(B).

261 Id. $\S 6123$ (c)(2).

262 Id. $\$ 6123(\mathrm{a})(1)$. This section reads as follows:

Upon the receipt of a report of the results of an examination ordered under Section 6122 (relating to mental competence examination) of this title, or of the results of treatment ordered under Section 6124 (relating to treatment to restore incompetent defendant) of this title, the court shall hold a hearing to determine competence.

Id.

263 Id. $\S 6124(\mathrm{e})(1)(\mathrm{A})$. 
finds the defendant still incompetent and orders continued treatment, ${ }^{264}$ a second report is required 230 days after the initial order. ${ }^{265}$ If the court finds the defendant still to be incompetent, the court may order only an additional ten days of treatment for the maximum period of treatment is 240 days. At that time, the court shall order the defendant's release and shall dismiss all charges against the defendant except class $A$ and $B$ felonies. ${ }^{266}$ In addition, the director of the facility must report to the court whenever it appears that the defendant has been restored to competency, through medication or otherwise, or the maximum benefit has been realized from the treatment. ${ }^{267}$ The report must include a description of the treatment provided, any improvement in the defendant's mental condition, any recommendation for future treatment, any change in prognosis from previous reports, and the probability that additional treatment will restore the defendant's competence. ${ }^{268}$

\section{RIGHT TO REFUSE CERTAIN TREATMENT}

The House bill includes provisions imposing strict requirements on the use of certain controversial treatment measures. The Senate bill contains similar provisions, ${ }^{269}$ but they will not be codified in title 18 . Instead, they are included in S. 1722 as conforming amendments to the Public Health Service Act. ${ }^{270}$ The Senate version thus contemplates that controversial treatment will be strictly regulated although the regulatory provisions are no longer included within S. 1722.271

The treatment provisions in H.R. 6915 require the Secretary of Health and Human Services to prescribe rules applying to the use of psychosurgery, electric shock treatment, and the protracted use of psychotropic drugs. ${ }^{272}$ Such regulations must provide for the right to accept or refuse the above types of treatment; ${ }^{273}$ and in order to ensure that the acceptance of such treatment is voluntary, the regulations must

264 Id. $\$ \S 6123(\mathrm{a})(1), 6123(\mathrm{~b})(2), 6123(\mathrm{c})(2)$.

$265 \mathrm{Id} . \S 6124(\mathrm{e})(\mathrm{l})(\mathrm{A})$.

266 Id. $\$ 6123$ (c)(1). See notes 243-45 \& accompanying text supra.

267 Id. $\S 6124(\mathrm{e})(1)(\mathrm{B})(\mathrm{i})$-(ii).

268 Id. § 6124(e)(2)-(3).

269 The text of these provisions is found in S. 1722, supra note 1, tit. VII, §611. See S. 1437, 95th Cong., 1st Sess. § 3616(j) (1977), a predecessor bill of S. 1722 that contained these provisions in the proposed recodification of title 18. The text of this section is contained in S. REP. No. 95-605, 95th Cong., 1st Sess. (1977).

27042 U.S.C. $\S 201$ et seg. (1976). These conforming amendments to provisions outside title 18 of the Code aztre designed to amend 42 U.S.C. § 242a (1976 \& Supp. III 1979).

271 See S. REP. No. $96-553$ at 1125 n.62.

272 H.R. 6915, supra note 2, §6124(d)(1)(A)-(B).

273 Id. $\S 6124(\mathrm{~d})(\mathrm{l})(\mathrm{C})(\mathrm{i})$. The conforming amendments in the Senate version are identical. S. 1722, supra note 1 . 


\section{require the informed consent of the patient-defendant. ${ }^{274}$ If the incom-}

274 H.R. 6915, supra note $2, \S 6124$ (d)(1)(C)(ii). In $\$ 6124$ (d)(4) and in the Senate version there is an exception to the consent requirement for emergency administrations of medication. See S. 1722, supra note 1. Additionally, the Senate amendments use the phrase "voluntary informed consent." Id.

A person's right to refuse certain treatments, as reflected in the Senate and House bills, may be traced to the due process clause of the fifth and fourteenth amendments. Among the historic liberties protected by the due process clause is "a right to be free from, and to obtain judicial relief for, unjustified intrusions on personal security." Ingraham v. Wright, 430 U.S. 651,673 (1977). Lower federal courts specifically have held that a mental patient, in a nonemergency situation, has the right to decide for himself whether to submit to serious and potentially harmful medical treatment that accompanies the administration of antipsychotic drugs, i.e., drugs used in treating psychoses, particularly schizophrenia. "Psychotropic" drugs, as used in the House and Senate bills, include antipsychotics, but also refer to potentially less harmful types of anti-depressant drugs. See, e.g., Rogers v. Okin, 634 F.2d 650 (Ist Cir. 1980); Rennie v. Klein, 462 F. Supp. 1131, 1144-45 (D.N.J. 1978) (on motion for preliminary injunction). The problem of defining a true "emergency" situation that would necessitate the forcible administration of the drugs has most recently been addressed in Rogers. In examining the limits of a state's police power to protect persons from physical harm at the hands of the mentally ill, the court of appeals rejected a lower court holding that a patient may be forcibly medicated where a failure to do so would result in a substantial likelihood (defined as "more likely than not") of physical harm to the patient, other patients, or to staff. 634 F.2d at 656-57. The Court of Appeals held:

[T] he district court should not attempt to fashion a single "more-likely-than-not" standard as a substitute for an individualized balancing of the varying interests of particular patients in refusing antipsychotic medication against the equally varying interests of patients-and the state-in preventing violence. Because we recognize the legitimacy of both of these interests, we conclude that neither should be allowed necessarily to override the other in a blanket fashion. Instead, the court should leave this difficult, necessarily ad hoc balancing to state physicians and limit its own role to designing procedures for ensuring that the patients' interests in refusing antipsychotics are taken into consideration and that antipsychotics are not forcibly administered absent a finding by a qualified physician that those interests are outweighed . . . and less restrictive alternatives are available.

Id.

The Rogers court also examined the permissible limits of a state's parens patriae power. Under such an interest, as distinguished from a police interest in preventing violence, the state seeks to provide care to those unable to care for themselves. The court held that, generally, a judicial determination of incapacity to make treatment decisions must be made before the state may rely on its parens patriae powers to forcibly administer medication. Id. at 657. However, the court went on to hold that an emergency situation would not require such a determination of incapacity before medication could be administered; and the court implied that a situation where delay could result in serious deterioration of mental health would constitute such an emergency. Id. at 659-60.

With respect to guardians of incapacitated patients, the court further held that it is not constitutionally required that the state must seek out the guardian for his approval of all treatment decisions. The court feared that a physician might be deterred from recommending potentially beneficial drug treatment due to the need to seek guardian approval. The court mandated that state actions must be taken, nevertheless, "with the aim of making treatment decisions as the individual himself would were he competent to do so." Id. at 661 . To ensure compliance with this requirement, the court suggested that there might be some procedure for a periodic review of a patient's treatment history by an independent physician. Id. To the extent that both H.R. 6915 and S. 1722 imply that a guardian is to be in more or less constant contact with the physician and his treatment plans, both bills appear to go beyond the Rogers holding. See note 275 \& accompanying text infra. 
petent defendant is incapable of giving informed consent by reason of his mental condition, such treatment may be permitted only with the permission of the defendant's guardian and with the permission of the court after a hearing at which the defendant is represented by counsel. ${ }^{275}$ No procedure is provided, however, for determining whether the defendant is capable of giving consent.

The House bill includes certain prerequisites for informed consent. First, the consent to treatment must be written on a consent form prescribed by the Secretary of Health and Human Services. ${ }^{276}$ Second, the defendant-patient must be given an oral explanation of the treatment at least twenty-four hours prior to signing the consent form. ${ }^{277}$ The consent form and the oral explanation must inform the defendant of the reason for the proposed treatment, the nature of the treatment, the likelihood of improvement with or without the treatment, the possible side effects of the treatment, the possible alternative treatments, and the right to refuse the treatment. ${ }^{278}$ The same information must be included in the written consent form. Third, both the oral explanation and the execution of the consent form shall be in the presence of at least one witness who is not associated with the treatment facility or with the proposed treatment. ${ }^{279}$ However, this disinterested witness need not be the defendant's attorney. Even more important; however, is the failure to include in these requirements the assistance of counsel. ${ }^{280}$ Although H.R. 6915 requires that the defendant-patient understand the oral explanation of the treatment prior to signing the consent form, there is no way to ensure an informed consent without the advice of counsel.

The very nature of the treating physician recommending the proposed treatment is inherently compulsive; and, if the defendant is confined for treatment, the nature of the setting adds to the compulsive

275 H.R. 6915, supra note $2, \S 6124(\mathrm{~d})(1)(\mathrm{C})(\mathrm{ii})$. The Senate version does not require a court hearing and court permission for such treatment of a defendant incapable of giving informed consent. All that is required for such treatment is the informed consent of a guardian or of any person appointed to represent the interests of the committed person. S. 1722, supra note 1 .

276 H.R. 6915, supra note 2, §6124(d)(2)(A)(i).

277 Id. $\S 6124(\mathrm{~d})(2)(\mathrm{A})(\mathrm{ii})$.

278 Id. $\$ 6124$ (d)(2)(B)(i)-(vi). The Senate version prescribes the same contents in a written consent form and an oral explanation at least 24 hours prior to the signing. S. 1722, supra note 1 .

279 H.R. 6915, supra note $2, \S 6124$ (d)(3). The Senate version is less specific, providing only that there be at least one "independent witness." S. 1722, supra note 1 .

280 The absence of counsel at this stage likely would not constitute denial of the sixth amendment right to counsel since this is not a critical pretrial stage at which the absence of counsel might seriously affect the subsequent criminal trial. See, e.g., United States v. Ash, 413 U.S. 300 (1973); Gilbert v. California, 388 U.S. 263 (1967); United States v. Wade, 388 U.S. 218 (1967). The Senate version also does not provide for the requirement of counsel to aid in any informed consent. S. 1722, supre note 1. 
atmosphere. Similar compulsive pressures led the Supreme Court to recognize the assistance of counsel in the custodial interrogation setting in order to ensure the free exercise of a defendant's right against selfincrimination. ${ }^{281}$ When a defendant has been found by a court to be incompetent, the need for the assistance of counsel becomes even greater. The defendant's mental state may mean that a true understanding of the proposed treatment is unlikely, or it may mean that the defendant is more susceptible to the recommendation for such treatment by his treating physician. In either case, consent would not be truly informed. The disinterested witness may help ameliorate or counter the compulsive pressures to give consent, but such a person's presence cannot ensure a knowing and intelligent consent. The House bill only requires the disinterested person's presence. No explicit provision allows for consultation between the witness and the defendant. Moreover, nothing requires that the witness act on behalf of the defendant, that the witness be known to the defendant, or that the witness be selected by the defendant. ${ }^{282}$ Nothing in the warning or the procedure would prevent the defendant from believing that the witness may be associated with the facility or with the person recommending the treatment. The defendant will not likely look to the witness for advice or for support in the event that the defendant desires to refuse such treatment.

In order to ensure a true informed consent, the defendant must have available to him a person whom he can be assured is acting on his behalf - a person whom he can trust. The defendant's attorney fills that role by reason of the attorney's professional obligation and by reason of the attorney's prior relationship with the defendant. Although it would be preferable to require actual consultation between the defendant and his attorney prior to signing any consent to treatment of such a controversial nature, certainly at a minimum the oral and written explanation of the proposed treatment should inform the defendant of his right to consult with his attorney or any other person of his choosing. ${ }^{283}$ Only by providing the right to consult with a person selected by the defend-

\footnotetext{
281 Miranda v. Arizona, 384 U.S. 436.

282 These deficiencies exist in the Senate version also. S. 1722, supra note 1.

283 Arguably, the right to counsel should also attach at this consent stage under a due process analysis. The Supreme Court has recognized that when an individual may be subjected to loss of liberty he is entitled to due process protections under the fifth and fourteenth amendments. See, e.g., Middendorf v. Henry, 425 U.S. 25, $42-43$ (1976); Mathews v. Eldridge, 424 U.S. 319, 332-33 (1976). Since the proposed medical treatments would, in effect, subject the individual to further control by the government beyond the control already exercised in keeping the individual physically confined in the mental facility, the treatments involve further intrusion on his liberty. Thus, the right to due process protection should attach at the consent stage. The question becomes, then, what process is due; specifically, the question is whether the right to due process at the determination to impose these treatments in cludes the right to counsel. The Supreme Court in Mathews set forth a test for deciding what
} 
ant can the defendant's right to refuse treatment be truly and scrupulously honored.

\section{RESTORATION OF COMPETENCY WITH THE AID OF MEDICATION OR DRUGS}

The House bill provides that a defendant who is otherwise incompetent to stand trial may proceed to trial if the administration of a psychotropic drug under medical supervision permits the defendant to maintain competence. ${ }^{284}$ However, even if the defendant maintains competence because of medication, the court may require that the defendant undergo treatment if the court finds that competence without the aid of medication is a substantial probability with treatment. ${ }^{285}$ In the case of drug-aided competency, the prescribing physician must inform the court, defense counsel, and the prosecutor of the fact that the

procedural safeguards are required as a part of due process in different settings. According to the Mathewes court:

[I]dentification of the specific dictates of due process generally requires consideration of three distinct factors: First, the private interest that will be affected by the official action; second, the risk of an erroneous deprivation of such interest through the procedures used, and the probable value, if any, of additional or substitute procedural safeguards; and finally, the Government's, interest, including the function involved and the fiscal and administrative burdens that the additional or substitute procedural requirement would entail.

424 U.S. at 335.

Therefore, in balancing these factors, right to counsel should be required as a matter of due process at this consent stage because (1) the private interest here involves a critical decision concerning whether to allow the government to interfere with an individual's mental functions, if only temporarily; (2) there is a great risk that without counsel an uninformed decision would be made because an already committed individual may be naturally confused and may not understand that he has a right to refuse the treatments, see notes 281-82 \& accompanying text supra, and (3) although there is a government interest in seeing that an individual regains competency through the use of certain treatments so that he may stand trial, providing the right to counsel would not necessarily frustrate that interest, but rather would serve to insure informed consent. Moreover, the cost of providing counsel would certainly be manageable since an indigent defendant would more than likely have a government-appointed counsel before the incompetency commitment, and this counsel could represent the defendant at the consent stage. Of couse, if a defendant was wealthy enough to afford counsel for a defense against the initial criminal charge, the presence of private counsel at this stage would not impose any fiscal burden on the government.

284 H.R. 6915, supra note 2, §6124(g)(1). The House committee cited Mental Health Law Project, supra note 8, at 627, for the proposition that the trial of defendants made competent through medication is generally preferable to prolonged incompetency commitments although such a trial is not an ideal situation. H.R. REP. No. 96-1396 at 558. Neither S. 1722 nor the present statutory law expressly provides for trials where the defendant is made competent through medication.

285 H.R. 6915, supra note 2, $\S 6124(\mathrm{~g})(2)$. The House committee here cited to Mental Health Law Project, supra note 8, at 627, stating that if a defendant " has some chance of being restored to competency to stand trial without ultimate reliance on medication (or without heavy dosages) he should be entitled to a reasonable delay for treatment.' " H.R. REP. No. 96-1396 at 558 . 
defendant is appearing in court under the influence of medication, including the type and dosage, and the possible effects of the medication on the defendant's appearance, actions, and general demeanor. ${ }^{286}$. If the defendant proceeds to trial under such medication, the defendant has the right to have the court inform the jury both at the beginning of the trial and in the jury instructions at the close of trial, about the defendant's use of the medication, the nature of the medication, and the probable effects on the defendant's demeanor and participation in the trial. ${ }^{287}$ The decision as to whether the jury should be informed of the defendant's medication is vested solely with the defendant. ${ }^{288}$ The defendant may choose to inform the jury or not, depending on the defense's assessment of the prejudicial nature of such information as compared to the prejudicial effect of the defendant's appearance or behavior due to the medication. ${ }^{289}$ The prosecutor and the court cannot override the defendant's assessment and decision by giving such an explanation to the jury over the defendant's objection. ${ }^{290}$

\section{E. LITIGATION OF GERTAIN ISSUES WHILE THE DEFENDANT IS INCOMPETENT}

The House bill includes a provision that permits defense counsel to litigate certain issues even though his client has been declared incompetent to stand trial. ${ }^{291}$ The Senate bill contains no similar provision. ${ }^{292}$ The issues that may be disposed of on behalf of an incompetent defend-

286 H.R. 6915 , supra note $2, \S 6124(\mathrm{~g})(3)$.

287 Id. $\S 6124(\mathrm{~g})(4)$.

$288 \mathrm{Id}$. This section provides that if the defendant proceeds to trial with the aid of medication, "the court, upon the motion of the defendant, shall provide to the jury, at the beginning of the trial and in the charge to the jury, an explanation of such medication and the medication's probable effects on the defendant's demeanor and participation in the trial." Id.

289 See, e.g. , State v. Murphy, 56 Wash. 2d 761, 355 P.2d 323 (1960), where the Washington Supreme Court reversed the murder conviction of a defendant who had been given a tranquilizer drug shortly before he took the witness stand. The drug enabled him to calmly recite the details of the murder for which he was on trial. The court concluded that there was a reasonable possibility that "his attitude, appearance, and demeanor, as observed by the jury, have been substantially influenced or affected by circumstances over which he had no real control." Id. at 768, 355 P.2d at 327.

290 The House committee cited Mental Health Law Project, supra note 8, at 627, for the belief that " in order to preclude the introduction of inflammatory and prejudicial information, the prosecution should not be able to introduce this [information concerning the defendant's use of the drug] into evidence.' " H.R. REP. NO. 96-1396 at 558.

291 H.R. 6915 , supra note $2, \S 6124$ (f). This section provides that even though a defendant is incompetent,

any defense motions which are susceptible to fair discrimination before trial and without the personal participation of the defendant may be made. An adverse ruling on a motion so made shall be without prejudice to the defendant's right to raise new factual evidence or considerations regarding the same matters in later proceedings in the case if competence is regained. Id. 
ant in H.R. 6915 are "any defense motions which are susceptible to fair determination before trial and without the personal participation of the defendant."293 Examples of some motions that would appear to meet the definition of this section include motions to dismiss on the grounds that the indictment is insufficient, that the statute of limitations has run, and that double jeopardy bars prosecution. ${ }^{294}$ Critical to this section is the determination by the defense counsel that the issue can be fairly disposed of without the participation or assistance of the defendant. This determination requires the exercise of discretion by counsel in the first instance; whether the court must entertain such a motion is not clear. The language of this section does not indicate whether the court must hear the motion or whether the court may refuse to hear the motion in the exercise of its discretion. Both the absence of any language about the court's role and the provision that any adverse ruling on such a motion shall be without prejudice to a defendant's right to raise the matter anew if competence is regained suggest that the court must entertain the motion. Even if the court does have discretion, it should give due deference to the determination of counsel as counsel is in the best position to ascertain the fairness of any litigation without the participation of his client.

Even if the incompetent defendant's attorney errs in his determination that a particular motion is susceptible of a fair determination while the defendant is incompetent, H.R. 6915 provides relief for a ruling against the defendant. Once competence is regained, the defendant may raise the issue again by presenting new evidence or considerations regarding the motion. ${ }^{295}$ By this provision the House bill insures that any ruling on a motion does not deny to a defendant his right to participate in the proceedings if his involvement would bring additional matters to bear on the ruling.

In allowing a procedure by which certain issues may be litigated while the defendant is incompetent to stand trial, H.R. 6915 recognizes that competence may vary with respect to different proceedings in a criminal case. Part of the definition of competence is that the defendant be able to assist in his own defense. ${ }^{296}$ Some defenses, however, are

292 Nor is there such an express statutory provision in the present federal law, 18 U.S.C. $\S \S 4244-48$.

293 H.R. 6915, supra note 2, §6124(f).

294 In Oregon, for example, these motions are specifically permitted despite the fact that the defendant is unfit to proceed to trial. OR. Rev. STAT. § 161.370(5) (1979). Other motions that would seem to fit the definition in $\S 6124(f)$ are motions to dismiss on the ground that the statute is unconstitutional and motions to suppress evidence when a search warrant is the subject of challenge.

295 H.R. 6915, supra note $2, \S 6124(\mathrm{f})$.

296 Id. §6129(a)(1). 
largely technical for which counsel does not need the assistance of his client. For many of such defenses, the defendant's incompetency. to stand trial on the merits is irrelevant. Also, an adverse ruling on such defenses does not necessarily involve a denial of due process. ${ }^{297}$ For example, a denial of a motion to dismiss on the ground that the statute is unconstitutionally vague does not require the defendant's participation, even if competent, and such a ruling is very different from the conviction of an incompetent defendant. For those motions that potentially involve the defendant's participation, for example, a motion to suppress illegally seized evidence, any due process issue presented by reason of the defendant's absence due to incompetence is obviated by permitting the defendant to relitigate the defense once competence is regained.

The failure of S. 1722 to include a provision allowing the incompetent defendant's counsel to litigate certain issues may impose unnecessary treatment and commitment on an incompetent defendant who may never be brought to trial for legal reasons unrelated to his incompetency. To the extent that H.R. 6915 permits the criminal charges to be disposed of on legal grounds prior to trial, the issue of incompetency is rendered irrelevant.

\section{CONCLUSION}

The Senate and House proposals for dealing with incompetency to stand trial represent significant improvements over the existing federal law. In addition to codifying federal caselaw that had developed and expanded the statutory framework, the bills incorporate many provisions that effect substantial reform in this area of the law. Among the major reforms are provisions that permit outpatient mental competence examinations, specify requirements for the contents of the report on the examination, set forth detailed procedures for the disposition of the incompetent defendant, and impose certain limitations on certain treatment of an incompetent defendant. Notwithstanding the problems in each bill that have been explored in this article, the proposals merit serious attention by the next Congress.

The House bill, the superior of the two bills, is an excellent starting point for the next Congress in continuing the effort to reform the law concerning incompetency to stand trial. Its provisions afford more expeditious resolution of many issues in a competency inquiry than does the Senate version. In addition, the House bill provides greater protection to the defendant who may be incompetent to stand trial. The House provisions for an initial screening examination and for the restoration of

297 See notes 9-11 \& accompanying text supra for a discussion of the due process basis underlying the requirement of competency to stand trial. 
competency with the aid of medication permit the court to expeditiously process cases in which the competency question has been raised. The dismissal of minor charges against an incompetent defendant for whom there is little likelihood of regaining competency and the disposition of cases on certain legal issues while the defendant is incompetent allow the court to clear its docket of cases that likely never will be brought to trial. These same provisions afford more safeguards to the defendant. Additional protections for the defendant in the House bill are included in provisions that authorize outpatient treatment of the incompetent defendant and that empower the court to discharge an incompetent defendant for whom treatment would be oppressive. In summary, the procedural advantages to both the court and the defendant in the House bill commend it over the Senate version as the model for future reform of the competence to stand trial provisions in the federal law. 